\title{
Mainstreaming Adaptation in National Development Planning
}

Juan Casado-Asensio, Anna Drutschinin, Jan Corfee-Morlot, and Gisela Campillo
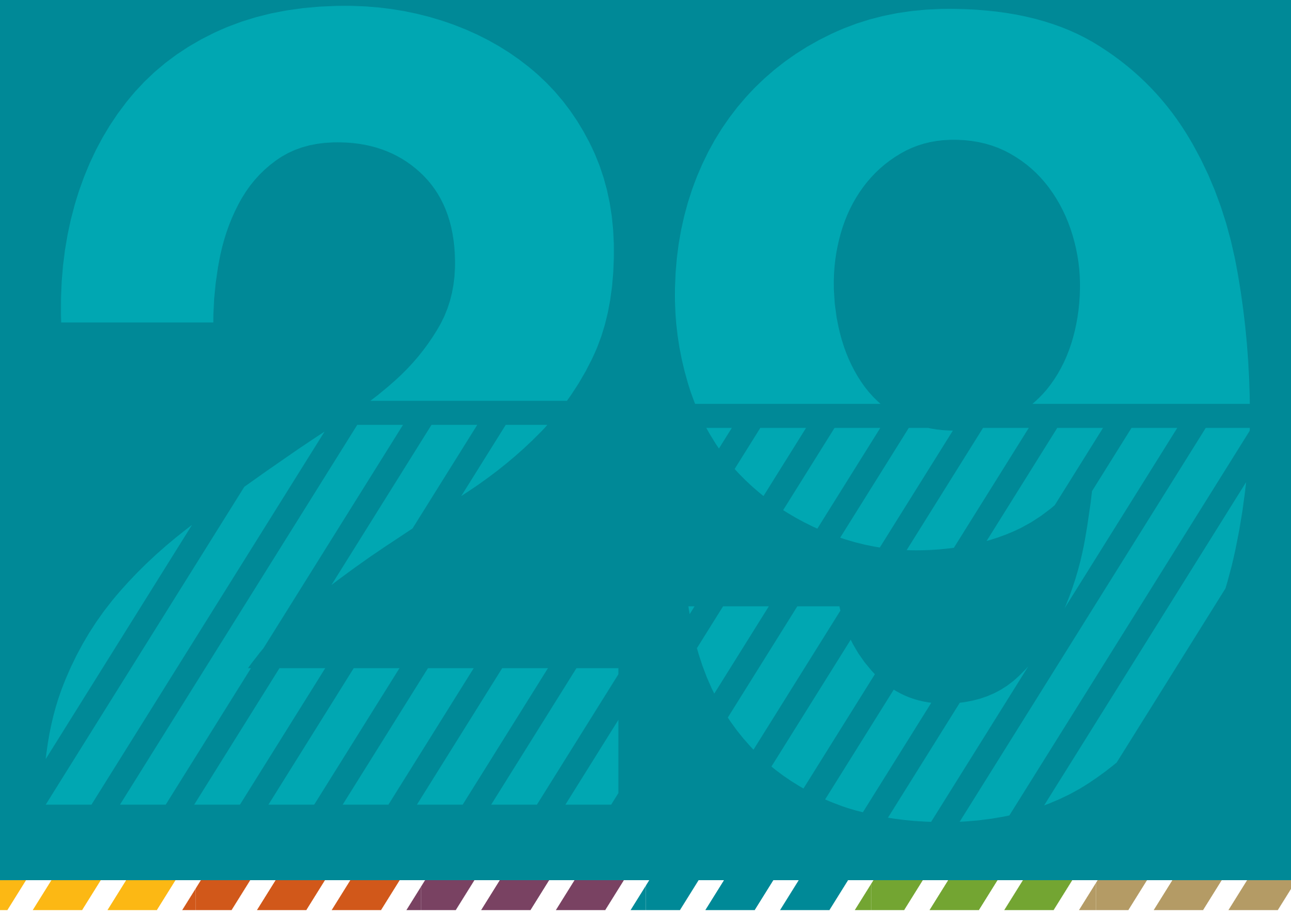

OECD DEVELOPMENT CO-OPERATION WORKING PAPER 29

Authorised for publication by Brenda Killen, Deputy Director, Development Co-operation Directorate



July 2016 


\section{OECD Development Co-operation Working Papers}

OECD Working Papers should not be reported as representing the official views of the OECD or of its member countries. The opinions expressed and arguments employed are those of the authors.

Working Papers describe preliminary results or research in progress by the author(s) and are published to stimulate discussion on a broad range of issues on which the OECD works. Comments on the present Working Paper are welcomed and may be sent to juan.casadoasensio@oecd.org - the Development Cooperation Directorate, OECD, 2 rue André-Pascal, 75775 Paris Cedex 16, France.

This document and any map included herein are without prejudice to the status of or sovereignty over any territory, to the delimitation of international frontiers and boundaries and to the name of any territory, city or area.

You can copy, download or print OECD content for your own use, and you can include excerpts from OECD publications, databases and multimedia products in your own documents, presentations, blogs, websites and teaching materials, provided that suitable acknowledgement of OECD as source and copyright owner is given. All requests for public or commercial use and translation rights should be submitted to rights@oecd.org. 


\title{
Mainstreaming Adaptation in National Development Planning
}

Juan Casado-Asensio, Anna Drutschinin, Jan Corfee-Morlot, and Gisela Campillo

\begin{abstract}
:
This Working Paper explores progress in the integration or mainstreaming of adaptation and related objectives into national development planning. It first provides an overview of the international mechanisms, including finance, to support the mainstreaming of climate change adaptation into development planning and policies in developing countries. Through a review of relevant planning documents in fifteen developing countries, it then examines key features in adaptation planning and mainstreaming of adaptation into development planning. These countries were because they have been amongst the highest recipients of adaptation-related bilateral development finance. The research provides a snapshot of current practice. Despite heightened international efforts to support developing countries, evidence of mainstreaming adaptation was only found in a few of the countries and in a few of the sectors studied here. It also found that where mainstreaming is occurring, linkages exist with other policy objectives including poverty reduction, promoting biodiversity and ecosystems, and urban and rural development. The findings may be a useful starting point to guide policy-relevant research, such as to what extent mainstreaming may be occurring on the ground (or not) and how well this progress is reflected in planning documents, as well as how to improve the effectiveness of development co-operation targeting adaptation. The paper may also help inform international efforts under the UNFCCC that are designed to support developing countries to mainstream adaptation priorities into development planning and policy.
\end{abstract}

Keywords: climate change, adaptation, development, mainstreaming

JEL Classification: N5; O13; O19; P48; Q56. 


\section{TABLE OF CONTENTS}



MAINSTREAMING ADAPTATION IN NATIONAL DEVELOPMENT PLANNING .............................4

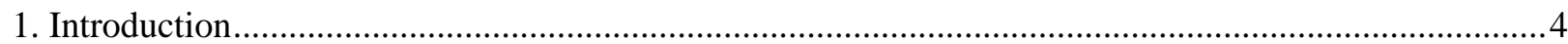

2. Key international developments on climate change adaptation....................................................... 7

3. International finance mechanisms and trends to support developing country adaptation activities ........9

4. The climate-development nexus: integrating development and adaptation planning at national level..14

4.1 Mainstreaming climate change adaptation in national development planning.................................14

4.2 Exploring linkages in national planning between adaptation and selected themes:

ecosystems, poverty and livelihoods, urban and rural development ...............................................17

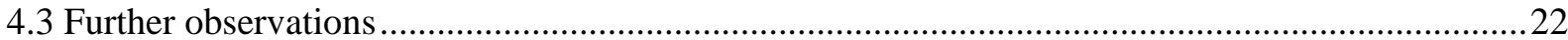

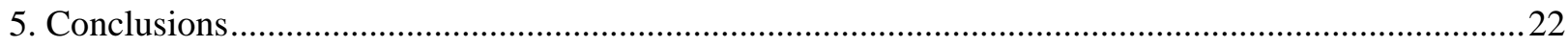

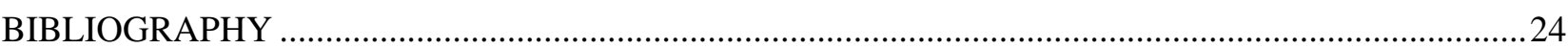



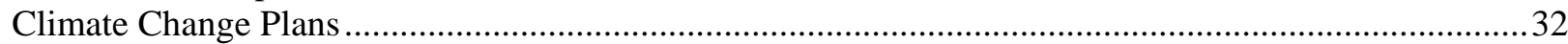

Annex 1. The extent to which climate change adaptation is integrated into national development plans in

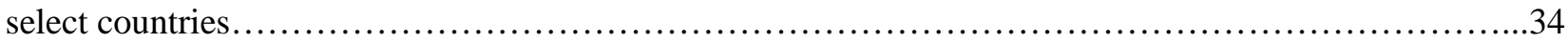
Annex 2. Linkages between adaptation and other environment and development issues in national

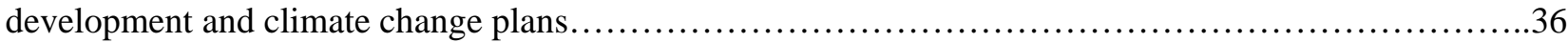

\section{Tables}

Table 1. Progress in implementing the National Adaptation Plans .....................................................9

Table 2. The extent to which climate change adaptation is integrated into national development plans in select countries: synthesis................................................... 16

Table 3. Adaptation linkages in national development plans .............................................................20

Table 4. Adaptation linkages in climate change plans......................................................................21

\section{Figures}

Figure 1. Bilateral adaptation-related development finance - 2010-14...............................................11

Figure 2. Bilateral and multilateral adaptation-related development finance in 2013 and 2014 .........13

\section{Boxes}

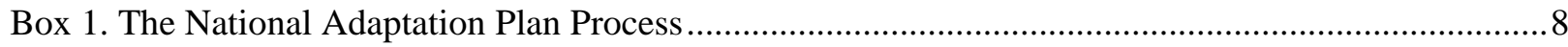

Box 2. The Pilot Program for Climate Resilience and the Zambian example .........................................10

Box 3. Development Assistance Committee Creditor Reporting System and the Rio markers ................12

Box 4. Ecosystem-based Adaptation ................................................................................................ 129 


\section{EXECUTIVE SUMMARY}

1. The 2030 Agenda for Sustainable Development emphasises the two-way relationship between environmental sustainability and poverty reduction. Achieving climate stability and promoting resilience is at the heart of the 2030 Agenda and ensuring good sustainable developmental outcomes will depend on how much attention is placed on this two-way relationship, especially in vulnerable developing countries.

2. Climate change has potentially devastating consequences for development. As a result, a number of international mechanisms exist under the United Nations Framework Convention on Climate Change (UNFCCC) to support countries to adapt to a changing climate. Adaptation policy has been in the international arena since the early 2000s, for example through processes designed to support least developed countries (LDCs) in the development of National Adaptation Programmes of Action (NAPAs) and National Adaptation Plans (NAPs).

3. Similarly, the UNFCCC has developed a number of financial mechanisms to support developing countries in adaptation, notably the Adaptation Fund, the Least Developed Countries Fund, or more recently the establishment of the Green Climate Fund. Bilateral and multilateral providers of development co-operation are also supporting climate change adaptation in developing countries and are increasingly honouring their climate-related commitments. Much of the international effort in this area has focused on ensuring that climate change adaptation is integrated into the core of development planning and policy, which in turn, ultimately ought to help to deliver resilience and sustainable development.

4. This paper considers the question of how the results of development co-operation efforts translate into the successful mainstreaming of adaptation in national or sub-national development strategies and plans. It begins by reviewing the adaptation-related international landscape (mandates, institutions, financial arrangements and flows), in particular looking for available tools and mechanisms at the international level that can help foster the mainstreaming of adaptation into development planning. As a second step, the paper examines evidence that mainstreaming of adaptation is occurring through a deskreview of national-level adaptation and development plans in 15 developing countries. The 15 countries are selected on the basis of being among the top bilateral aid recipients for assistance targeting climate change adaptation.

5. Despite heightened interest and levels of international financial support for climate change adaptation, the review found uneven recognition of adaptation and related notions in the national planning documents of the 15 countries. The review also looked at whether and how adaptation is linking to a range of relevant development themes in national development plans. Here the paper finds that those countries better mainstreaming adaptation usually connect the issue of climate change risk management or adaptation with other policy priorities, such as poverty reduction, promoting biodiversity and ecosystems, and urban and rural development.

6. The approach of the paper is desk-based research and therefore it can only provide an initial and general snapshot of the state and features of mainstreaming of adaptation in the national development planning. And its scope is limited to a handful of countries. To better understand and verify the patterns identified, and the drivers of these patterns, would require more in-depth research. Key would be to look into whether the mainstreaming featured in planning documents is also reflected on the ground across relevant national and local policies and institutional practices. Despite strong external support for adaptation planning, why is mainstreaming more advanced in some countries but not in others? Answering the question of "why" adaptation mainstreaming is slow and unevenly occurring across countries and could provide insights into more effective design of development co-operation and policy. 


\title{
MAINSTREAMING ADAPTATION IN NATIONAL DEVELOPMENT PLANNING
}

\author{
"Humans are transforming the planet in ways that could undermine development gains."
}

Griggs et al., 2013

\section{Introduction}

7. The 2030 Agenda for Sustainable Development (United Nations, 2015) establishes seventeen universal and ambitious Sustainable Development Goals (SDGs) that will guide development planning over the decades to come. Agenda 2030 emphasises the two-way relationship between environmental sustainability and poverty reduction, underscoring the linkages to successful development outcomes. There is a wealth of research to support Agenda 2030 and the need to fundamentally transform the way we develop. Griggs et al. (2013), for example, argued persuasively that "protection of Earth's life-support system and poverty reduction must be the twin priorities for the SDGs" (see also Rockström et al., 2009). This view is now well-accepted and embedded in Agenda 2030 as well as the Paris Agreement on climate change (UNFCCC, 2015). While both documents focus on achieving climate stability and promoting resilience, the Paris Agreement emphasises the importance of enhancing adaptive capacity, and reducing vulnerability (see Articles 2.1 and 7.1, UNFCCC, 2015). A key outcome of the Paris Agreement is international endorsement of an ambitious long-term goal for climate stability to "hold the increase in the global average temperature to well below $2{ }^{\circ} \mathrm{C}$ above pre-industrial levels and pursuing efforts to limit the temperature increase to $1.5^{\circ} \mathrm{C}$ above pre-industrial levels” (UNFCCC, 2015).

8. Yet even achievement of the 2 or $1.5^{\circ} \mathrm{C}$ temperature goals over the long-term will not avoid all future climate impacts (Naidoo et al., 2012; Peters et al., 2012). Indeed some changes in the climate are already being observed today (IPCC, 2014). The Paris Agreement emphasises, inter alia, the need to adapt to climate change and recognises that action is required by all countries, particularly those most exposed to the adverse impacts of climate change and that lack the capacity to address heightened risks ${ }^{1}$. It further highlights that these countries are often also the poorest and will therefore require urgent assistance. Adaptation entails adjusting natural and human systems in response to actual or anticipated changes in climatic conditions and their effects (IPCC, 2001); and enhancing the capacity of individuals, households, communities and countries to absorb, adapt, manage and transform to increased climate shocks and risks (OECD, 2013a, 2014).

9. Development and adaptation are not always complementary and unless carefully planned, poverty reduction efforts may heighten vulnerability to climate change for particular groups or across spatial and temporal scales (Eriksen and O’Brien, 2007; Tanner and Horn-Phathanothai, 2013; OECD, 2014). Indeed, future threats may take root in current forms of development that are not always sustainable. For example, poorly managed urbanisation or coastal development leads to the degradation of watersheds or forest ecosystems and the disruption of the critical services that they provide to support human wellbeing such as clean water, air and a stable climate (Rockström et al. 2009; Griggs et al. 2013). Climate change will exacerbate the vulnerabilities arising from these unsustainable trends (IPCC, 2014). In addition, activities promoting development will quickly become inadequate to cope with heightened

\footnotetext{
${ }^{1}$ Such as the least developed countries (LDCs), land-locked developing countries (LLDCs) or small island developing states (SIDS).
} 
climate change risks, unless these risks are explicitly taken into account in planning (OECD, 2009). Investments in energy, transport and water infrastructure provide an illustration (OECD, 2014). Ideally, responses to climate change will be mainstreamed in national development planning and policy, as well as in the activities of development co-operation providers, to avoid cases of maladaptation where development investments increase vulnerability and exacerbate climate change risks; mainstreamed adaptation responses will also identify co-benefits, tackle trade-offs and promote synergies between development and adaptation (OECD, 2005; IPCC, 2007).

10. Although impacts are location-specific and large variations are expected across regions, climate change impacts will affect disproportionately developing countries and the poorest people in these countries (OECD, 2009). It is estimated that developing countries will bear approximately four-fifths of the costs caused by a $2^{\circ} \mathrm{C}$ increase in average global temperature (World Bank, 2010). The net economic consequences of climate change will be particularly severe in Africa and Asia, where economies are more vulnerable (OECD, 2015a). For example, agricultural yields are estimated to drop by 5-25\% by 2060. This is particularly true in least developed countries (LDCs) and other developing countries, where heightened exposure to climate change impacts compounds with high levels of vulnerability due to:

- Dependence on climate-sensitive natural resources (e.g. wood, water, land) and the services provided by ecosystems (e.g. mangrove forests). It is estimated that natural capital provides $47 \%$ to $90 \%$ of income in poorer countries (UNEP, 2011);

- Limited ability to adapt to the direct and indirect effects of climate change for socio-economic, environmental and political reasons. Many developing countries have relatively small economies, poorly developed infrastructure, suffer from chronic poverty, limited resources and insufficient capacity and structure for good governance (World Bank, 2004; OECD, 2013b);

- Higher exposure to climatic hazards due to uncontrolled urban growth and poverty, with the poorest often settling in marginal lands (e.g. flood plains), cultivating depleted soils or relying on stressed natural environments (OECD, 2013b).

11. Climate change puts pressure on the very foundations of development and growth, and may undermine if not reverse hard-earned development gains of recent years, including improved access to energy, clean water, food security and sanitation (OECD, 2009). If development is understood as the effort to improve human well-being with a focus on poverty reduction (OECD, 2007a), then adaptation may be driven by the need to reduce the negative climate impacts on development and growth (AfDB et al., 2003; McGray et al., 2007; UNDP, 2007; World Bank, 2012). Yet overall, policy communities in developing and developed countries are at the early stages of understanding how adaptation fits in development planning and policy (OECD, 2014; UNFCCC, 2013).

12. National actors in developing countries lead development efforts that are driven by goals, strategies, projects, plans, and policies (e.g. national development plans or strategies). The increasing presence of explicit linkages to climate change adaptation in national development planning and policy is a recent trend (Tanner and Horn-Phathanothai, 2013). Attention to adaptation was partly driven by international instruments, bodies and support mechanisms under the United Nations Framework Convention on Climate Change (UNFCCC, 2013); and partly by the activities of providers of development co-operation.

13. A key milestone in this process was the launch of National Adaptation Plans of Action (NAPAs) for LDCs through the UNFCCC in 2001, with the aim to assist LDCs to address urgent adaptation priorities. More recently, the 2010 Cancun Adaptation Framework called for the development of National Adaptation Plans (NAPs) in all developing countries. The Paris Agreement not only enshrines the goal of 
"enhancing adaptive capacity, strengthening resilience and reducing vulnerability to climate change”, but also links adaptation to the mitigation goal of limiting global temperatures. Furthermore, the Agreement mandates the inclusion of adaptation in country climate plans, which are revised periodically, and can therefore stimulate and accelerate adaptation action over time (Article 7, UNFCCC, 2015). Finally, the Agreement also details the various processes of what could constitute "effective" mainstreaming (Art. 7.9, UNFCCC, 2015).

14. Providers of development co-operation have been supporting these efforts, and in 2014 members of the OECD Development Assistance Committee (DAC) committed up to USD 12.4 billion of bilateral official development assistance (ODA) targeting climate change adaptation goals (OECD DAC CRS, 2016). This represented $10 \%$ of total climate-related ODA in 2014. The "lower bound" of total bilateral adaptation ODA commitments, reflecting activities where adaptation is the principal objective, stands at USD 3.8 billion. Bilateral ODA targeting climate change mitigation dwarfs the commitments targeting adaptation because adaptation is a more recent concern and adaptation-related interventions are more complex to design. Nonetheless, adaptation is now a significant and growing target of ODA flowing through bilateral and multilateral channels.

15. This paper explores the international landscape, guidance and mechanisms that promote the integration of climate change adaptation in national development policy and planning, which is an important element of "mainstreaming adaptation." Mainstreaming adaptation is here defined as the integration of adaptation in policy- and decision-making processes, outputs and outcomes, across different levels of governance and entry points (national, sectoral, local). To be effective, mainstreaming adaptation in development planning and policy should ensure that the implementation mandate for adaptation moves beyond specialised environmental agencies or disaster risk reduction authorities, which usually lead the formulation and implementation of adaptation plans (Huq and Reid, 2005; OECD, 2005, 2009). As the drivers of adaptation do not always fit neatly within existing sector boundaries, it is useful to consider a range of cross-sectoral issues that can be integrated across sectors and levels of government (Smit and Wandel, 2006; McGray et al. 2007; WRI, 2011). Examples of cross-sectoral themes that provide entry points for adaptation include, e.g. urban development, natural resource management and coastal zone management. Using these themes to approach mainstreaming could lower the risks of maladaptation by helping to join-up relevant knowledge, financial resources and decision and policy-making processes (Urwin and Jordan, 2008; Mickwitz et al., 2009). To this end, effective adaptation action requires institutional design and reform, building of technical and organisational capacity as well as the development of strong monitoring and evaluation frameworks to facilitate learning (OECD, 2008; DalalClayton and Bass, 2009).

16. This paper therefore examines to what extent and where adaptation priorities are reflected in national development planning by conducting key word searches of the national development plans of 15 developing countries, and using the presence of these words as a proxy for mainstreaming. These countries were reviewed based on i) the level of development assistance committed to adaptation, both in absolute (total amounts committed) and relative terms (relative to total climate-related ODA committed to the country) and ii) to ensure a balanced representation of world regions. All major regions are represented, and the 15 countries received 29\% of total bilateral adaptation-related ODA over 2010-14. A word search of national development and climate change plans explored how adaptation is linked to: poverty reduction, biodiversity and ecosystems, and urban and rural development.

17. Being desk-based, this paper does not provide a comprehensive state of play of adaptation mainstreaming in developing countries. Rather, the research presents a snapshot of where, how and to what extent adaptation is reflected in the key planning documents of top recipients of adaptation-related ODA, and provides a base for further work. This research can inform international efforts to support developing countries to mainstream adaptation in development planning and policy priorities and as well as country- 
led efforts on adaptation. The target audience for this research is adaptation policy practitioners in developing countries, particularly with respect to recently launched NAP processes, and providers of development co-operation (e.g. by indicating how they might best target and prioritise their interventions on adaptation).

\section{Key international developments on climate change adaptation}

18. Historically, climate change adaptation has received far less political attention in the international arena than mitigation. This had to do with the difficulty in defining what is meant by "climate change adaptation" (see Gilbert et al., 2010) and consequently of defining adaptation-related interventions, policy and finance (e.g. Terpstra et al., 2013), including ways for public adaptation finance to mobilise private finance (Kato et al., 2014). Consequently, fewer international institutional mechanisms such as those under the UNFCCC target adaptation and, partly as a result of this, adaptation has received lower levels of international financial assistance over time (Kato et al., 2014).

19. As noted, 2001 marked the first year in the international arena when UNFCCC Parties adopted guidelines for the selection and implementation of "immediate and urgent" measures through NAPAs in LDCs (Annex A to decision 28/CP.7, UNFCCC, 2002). Country-led NAPAs were meant to complement ongoing national-level development approaches. As such, NAPAs constituted the first opportunity for LDCs to undertake climate-related studies and to align adaptation projects with development priorities (Dessai and Schipper, 2003; UNFCCC/LEG, 2011; Pauw and Pegels, 2013). NAPAs use an eight-step process for governments to prioritise a list of projects, with financial support from the LDC Fund and technical guidance through the LDC Expert Group (LEG).

20. Although all LDCs submitted a NAPA to the UNFCCC Secretariat, few actually mainstreamed adaptation in national planning and policy (Helgeson and Ellis, 2015). In fact, most NAPAs contain sectorspecific projects, concrete development-related interventions and, at most, aim to build capacity and raise awareness on the issue (Helgeson and Ellis, 2015). Early assessments of NAPAs note several challenges that prevented LDCs from effectively mainstreaming adaptation (UNFCCC/LEG, 2012). These include:

- a lack of technical skills and capacity to carry out in-depth impact vulnerability and adaptation assessments across sectors and scales, and to mainstream adaptation.

- a funding gap to implement adaptation policy.

- a lack of cost-effective and environmentally sound technologies.

- a limited awareness of climate change among relevant public and private sector actors.

21. At COP 16 in Cancun (2010), UNFCCC Parties launched the National Adaptation Plan (NAP) process, which revised and updated NAPAs (see Box 1). NAPs were extended to all developing countries and were meant to guide them into comprehensive, long-term planning for adaptation (unlike NAPAs). Building on this mandate and on successful experience in sharing knowledge and promoting synergies between development and adaptation planning at country-level during the NAPA process, the LEG developed Technical Guidelines for the National Adaptation Plan Process, designed to help LDCs integrate adaptation in national development planning and policy effectively (UNFCCC/LEG, 2012). The LEG has also been supporting knowledge-sharing across developing countries to inform approaches to deal with these challenges. In particular, it conducts workshops (e.g. NAP Regional Workshop in Eastern and Southern Africa or the Pacific; NAP Global Expos; NAP Central information repository) and develops technical guidance and related publications (e.g. supplements to the Technical Guidance), with funding channelled through the UNFCCC Secretariat. 


\section{Box 1. The National Adaptation Plan Process}

The National Adaptation Plan (NAP) process provides an opportunity for developing countries to address their medium- and long-term adaptation needs. In LDCs, the process builds on the National Adaptation Programmes of Action (NAPA) experiences and arrangements. NAPs aim to reduce developing countries' vulnerability to the impacts of climate change by building adaptive capacity and resilience. NAPs seek to enhance the coherence of adaptation and development planning within countries and facilitate country-owned, country-driven action; they are not prescriptive and are designed so that countries can monitor, review and update them in an iterative manner. The NAP process is intended to be comprehensive, on-going and long-term.

NAPs are co-ordinated with national sustainable development objectives, plans, policies and programmes at their centre, which is why consolidating adaptation activities and co-ordinating these within all relevant sectors and at different levels, as appropriate, are important elements of the NAP process. NAPs help to prioritise activities to prevent negative climate impacts on development, while helping manage the multiple stress factors that combine in complex ways across temporal and geographic scales in a country. The NAP process is also designed to encourage adequate and predictable external support which takes into account the comprehensive, continuous and iterative nature of the NAP process, and aims to identify the level of climate risk that can be addressed given socio-economic and ecological constraints.

The UNFCCC/LEG developed Technical Guidelines for the NAP process to support LDCs towards "effective adaptation planning and policy." These guidelines (currently being reviewed by the Adaptation Committee for nonLDCs) cover four areas: (a) laying the groundwork and addressing gaps (e.g. build the knowledge base by providing or developing historical climate trends, scenarios, impacts, risks and vulnerability); (b) assessing preparatory elements (e.g. identifying options and policy/institutional responses, such as cross-sector trade-offs and synergies; establishing adaptation institutions; formulation/modification of policies); (c) implementing strategies (e.g. ensuring co-ordination across sectors, levels of government and stakeholders); and (d) reporting, monitoring and reviewing implementation. The Guidelines provide an indicative list of activities under four pillars, arranged into steps (UNFCCC/LEG, 2012). The planning of activities and the way these are sequenced will depend on national circumstances and are to be determined by countries themselves.

Under a NAP, the planning and implementation of adaptation is therefore based on nationally identified priorities, including those reflected in the relevant national documents, plans and strategies. The process is designed so that it can be integrated into national plans as appropriate, ensuring continuity and learning in planning and implementing adaptation, and to communicate progress through iterative outputs that build on insights and experience gained over time. In turn, this iterative NAP process should increase confidence amongst development co-operation providers to support a country-owned, country-driven process that requires strategic action and planning that goes beyond the implementation of one-off adaptation projects.

Source: UNFCCC/LEG (2012). Technical Guidelines for the National Adaptation Plan Process, UNFCCC Secretariat, Bonn.

22. Other arrangements are also in place under the UNFCCC to support the NAP process. For example, the Subsidiary Body for Scientific and Technological Advice is responsible for overseeing the Nairobi Work Programme on impacts, vulnerability and adaptation to climate change (agreed at COP11 in Nairobi in 2005). It provides assistance to developing countries to improve assessment of climate change impacts and make informed decisions on national adaptation actions and measures. Additionally, the Adaptation Committee provides technical support and guidance to parties on adaptation action and means of implementation and promotes awareness-raising, outreach and sharing of information. Since 2013, the work of the Adaptation Committee also feeds into the Nairobi Work Programme.

23. By May 2016, most LDCs had provided information to the UNFCCC on the measures taken to develop a NAP but only two countries had submitted a NAP (Burkina Faso and Cameroon, both in October 2015). The measures reported vary across developing countries. Most relate to laying the groundwork, addressing gaps and assessing country needs, while a few countries are actually implementing activities to move in the direction of the NAP process (see Table 1; Hegelson and Ellis). Also, about 30 of all so-called Intended Nationally Determined Contributions (INDCs) or national climate action plans submitted to the UNFCCC ahead of the Conference of the Parties meeting in Paris (COP21) in December 2015, explicitly 
mentioned plans to develop a NAP in the adaptation component (Kato and Ellis, 2016). Most INDCs, too, included an adaptation component (WRI, 2015).

Table 1. Progress in implementing the National Adaptation Plans

\begin{tabular}{|l|l|}
\hline \multicolumn{1}{|c|}{ Activities } & \multicolumn{1}{c|}{ Countries } \\
\hline 1. Laying the groundwork and addressing gaps & \multicolumn{1}{c|}{} \\
\hline Multi-stakeholder workshops & Benin, Burkina Faso, Jamaica, Malawi, Tanzania, Togo \\
\hline $\begin{array}{l}\text { Assessments of available country-specific information on } \\
\text { climate-related impacts, vulnerability and adaptation }\end{array}$ & Cambodia, Cameroon, Lesotho, Niger, Togo \\
\hline 2. Assessing preparatory elements & $\begin{array}{l}\text { Benin, Burkina Faso, Cameroon, Democratic Republic of } \\
\text { Congo, the Gambia, Guinea-Bissau, Liberia, Malawi, } \\
\text { Nepal, Senegal, Sudan }\end{array}$ \\
\hline Discussions on needs and gaps assessments & Burkina Faso, Cameroon, Lesotho, Tanzania \\
\hline Risk and vulnerability assessments & $\begin{array}{l}\text { Bangladesh, Burkina Faso, Cambodia, Cameroon, } \\
\text { Gambia, Liberia, Malawi, Niger, Togo, Tanzania }\end{array}$ \\
\hline Roadmaps for the NAP process & $\begin{array}{l}\text { Bhutan, Bolivia, Burkina Faso, Cameroon, India, } \\
\text { Indonesia, Mali, Morocco, Mozambique, Tanzania, } \\
\text { Vanuatu, Viet Nam }\end{array}$ \\
\hline $\begin{array}{l}\text { 3. Implementation of strategies } \\
\text { sectoral planning }\end{array}$ & Burkina Faso, Cameroon \\
\hline 4. Report, monitor and review implementation & \\
\hline Monitor the NAP process &
\end{tabular}

Source: Helgeson and Ellis, 2015; Authors' research

\section{International finance mechanisms and trends to support developing country adaptation activities}

24. International financial flows are essential for supporting adaptation efforts in developing countries. The main sources of funding are the dedicated mechanisms under the UNFCCC and the Climate Investment Funds. In addition, bilateral climate change adaptation-related development finance has been increasing, both in volume and as a share of total ODA, reflecting the increasing integration of adaptationrelated concerns in bilateral development co-operation.

25. Article 11 of the UNFCCC defines a financial mechanism to provide resources to developing countries. Its operation was entrusted to the Global Environmental Facility (GEF), which now operates three funds supporting adaptation activities in developing countries to varying degrees:

- The GEF Trust Fund which supports enabling activities, notably for reporting on adaptation and other climate change activities under the Convention;

- The Least Developed Countries Fund (LDCF), which supports the preparation and implementation of NAPAs and NAPs; and

- The Special Climate Change Fund (SCCF), which finances non-LDC pilot or demonstration adaptation activities and NAPs. 
26. The GEF has also created a NAPs Support Programme to specifically assist LDCs. In addition, under the Kyoto Protocol, the Adaptation Fund supports adaptation projects and programmes in vulnerable developing countries. Adaptation finance is also being channelled through the Green Climate Fund, which recently agreed to target vulnerable developing countries and to devote half of its portfolio to adaptation (GCF, 2014). In late 2015, a first round of eight projects were approved through the GCF for funding, with the majority of these projects centring on adaptation-related activities worth USD 168 million in Africa, Asia-Pacific and Latin America (GCF, 2015).

\section{Box 2. The Pilot Program for Climate Resilience in Zambia}

The Pilot Program for Climate Resilience (PPCR) is funded by the Strategic Climate Fund, one of the two Climate Investment Funds (CIFs). It is designed to demonstrate ways that developing countries can make climate risk and resilience part of their core development planning. It helps countries build on their National Adaptation Programs of Action and helps fund public and private sector investments identified in climate resilient development plans; its work to support countries is compatible with the NAP process.

Under the PPCR, approximately USD 1.3 billion has been pledged to support PPCRs in nine countries (Bangladesh, Bolivia, Cambodia, Mozambique, Nepal, Niger, Tajikistan, Yemen, and Zambia), as well as in two regions, namely in the Caribbean (Dominica, Grenada, Haiti, Jamaica, St. Lucia, St. Vincent and the Grenadines) and the Pacific (Papua New Guinea, Samoa, Tonga). All Strategic Programs for Climate Resilience have been endorsed by the PPCR Sub-Committee. A pipeline of 66 projects and programmes has emerged from the PPCR work with these countries. To date, the PPCR is funding 32 projects totalling USD 616 million in grant funding, and is expected to leverage another USD 784 million in co-financing.

The Zambian PPCR programme, for example, includes an investment strategy in line with national development priorities, which received a development grant of USD 1.5 million. The investment strategy aims at strengthening early warning weather systems, integrating climate resilience in infrastructure planning and investments, and strengthening natural ecosystems and the adaptive capacity and livelihoods of farmers in the most affected areas of southern and western Zambia. To do so, the African Development Bank is supporting this phase by: providing input on mainstreaming climate resilience into national development planning; strengthening institutional co-ordination and improving information for decision-makers; and shaping targeted awareness and communication. This has: given individual ministries the mandate to work on climate change issues, as budget allocations were linked to the strategy; strengthened country ownership and effectiveness by promoting institutional reforms on adaptation planning; and improved the political economy context through concessional finance (Climate Investment Funds, 2014). This has translated into three concrete interventions covering a range of sectors: two projects on building resilience in landbased livelihoods and infrastructure in two river sub-basins, and one on private sector support for climate resilience in those same sub-basins.

Source: Climate Investment Funds (2014), Learning by Doing: The CIFs Contribution to Climate Finance; and ClFs website: www.climateinvestmentfunds.org (accessed December 2014); Climate Investment Funds (2012), Pilot Program on Climate Resilience (PPCR) Semi-Annual Operational Report, PPCR/SC.11/3.Rev.1, October 19, 2012 - Meeting of the PPCR Sub-Committee Istanbul, Turkey.

27. Lastly, the Climate Investment Funds' (CIFs) Pilot Program for Climate Resilience (PPCR) supports the integration and implementation of climate risk and resilience into national development planning and implementation through "catalytic" interventions (CIF, 2009, 2013). The PPCR supports countries in developing their Strategic Programs for Climate Resilience (SPCRs), which outline country priorities, visions and strategy for integrating climate resilience into development planning (and in fact mainstreaming constitutes one of the core indicators). SPCRs build on the NAPAs and other national development programmes and plans, and are compatible with the NAP process. So far the PPCR is supporting highly vulnerable countries, while all SPCRs are at different stages of implementation (see Box 2; CIF, 2013 and 2014).

28. Since 2009, the UNFCCC has also formalised two collective international climate finance commitments on behalf of developed country parties to support developing countries take climate change action, including adaptation. These commitments include: i) the "Fast Start Finance" commitment to 
provide new and additional resources approaching USD 30 billion to developing countries for the period 2010-12 with balanced allocation between mitigation and adaptation; and ii) a goal to jointly mobilise USD 100 billion per year by 2020 from a wide variety of sources, both public and private. Finally, the 2015 Paris Agreement includes a provision on scaling-up financial resources to achieve a balance between climate change adaptation and mitigation, taking into account country-driven strategies and the priorities and needs of developing countries, especially those that are vulnerable and/or with significant capacity constraints, such as LDCs and SIDS (Article 9.4, UNFCCC 2015).

29. In addition, a significant share of the flows reported by developed countries to fulfil these commitments is channelled bilaterally in the form of ODA (OECD-CPI, 2015). Providers of development co-operation have been increasing their adaptation-related ODA. According to the OECD DAC Creditor Reporting System (CRS) (see Box 3), ODA commitments targeting adaptation reached USD 10.3 billion on average per year in 2010-2014, representing 8\% of total ODA commitments (Figure 1).

Figure 1. Bilateral adaptation-related development finance 2010-14

Bilateral commitments, USD billion, annual and 2-year annual average, constant 2013 prices



30. Of total bilateral adaptation-related ODA from DAC members, about 30\% (USD 3.0 billion on average per year) targets adaptation as a principal objective, while 70\% (USD 7.2 billion on average per year) targets adaptation as a significant objective (see Figure 1). This indicates that development cooperation providers are integrating adaptation considerations into development co-operation activities with other primary objectives. It also shows that providers are recognising adaptation co-benefits of activities primarily targeting other environmental and climate-related objectives, such as mitigation (45\% of adaptation activities also target mitigation), biodiversity (35\%) and desertification (16\%). 


\section{Box 3. The Development Assistance Committee Creditor Reporting System and the Rio markers}

Developed countries signing the three Rio Conventions on Climate Change, Biological Diversity and Desertification in 1992 committed to assist developing countries in the implementation of these Conventions through the provision of finance among other forms of support. The DAC monitors development finance targeting the global environmental objectives of the Rio Conventions through its Creditor Reporting System (CRS) using the "Rio markers." The markers are designed to track the integration of environmental objectives into development co-operation portfolios rather than specific quantitative financial commitments and thus the Rio marker data provide a range for adaptationrelated bilateral development finance. The sum of ODA targeting adaptation as a principal objective and ODA targeting adaptation as a significant objective can be considered as the "upper bound", while ODA targeting adaptation as a principal objective can be considered as the "lower bound."

The Rio marker for adaptation was introduced in 2010. It is applied to activities that intend to reduce the vulnerability of human or natural systems to the current and expected impacts of climate change, including climate variability, by maintaining or increasing resilience, through increased ability to adapt to, or absorb, climate change stresses, shocks and variability and/or by helping reduce exposure to them. This encompasses a range of activities from information and knowledge generation, to capacity development, planning and the implementation of climate change adaptation actions (OECD, 2007b). By way of background, the CRS contains details of over 4000 climate adaptation-related ODA activities per year since 2010, reaching over 5400 in 2014.

It is useful to highlight some of the strengths and the weaknesses of the DAC CRS dataset for adaptation related development finance. In terms of the strengths, it is the only statistical system available for tracking official development finance targeting the objectives of the Rio Conventions and as such is the most comprehensive and comparable source of data available. Aggregate figures are derived from activity-level reporting with over 50 fields of detail, and the dataset is publicly available online. This provides a high level of transparency around what types of activities are being reported as adaptation (or mitigation). The data provide detail on the type of finance (grant or loan, concessional or non-concessional) and on the destination (country, sector), as well as the source (country) and the channel (bilateral or multilateral).

Several shortcomings of the Rio markers for climate finance must also be acknowledged. In particular, data on adaptation are available only from 2010, making it difficult to discern trends particularly compared to mitigation where the marker has been in place since 1998 (but only obligatory since 2007). Also, while many OECD countries draw on the Rio marker data to report their climate-related finance to the UNFCCC, they generally only report a portion of activities marked as targeting mitigation and/or adaptation as a significant objective through the application of coefficients; however, there is no agreed common approach for this practice (OECD-CPI, 2015). There is also concern about the consistency in marking across reporting countries; for example, Jungans and Harmeling (2012) found that project marking may over-estimate the adaptation relevance of projects. Coverage of the Rio marker data may also be incomplete. For example, information to identify particular flows such as recipients or location may be absent from the system, making it difficult to track activities on the ground (Terpstra et al. 2013). Additionally, while countries are required to apply Rio markers to other official flows (OOF) (i.e. non-concessional finance) since 2010, this practice is still only partial. Finally, information is lacking to track disbursements as opposed to commitments, which makes it more difficult to get a picture of actual bilateral development finance flowing into partner developing countries.

Source: OECD (2007b), Reporting Directives for the Creditor Reporting System, Addendum on the Climate Change Adaptation Marker (DCD/DAC(2007)39/FINAL/ADD3), OECD, Paris; Junghans, L. and S. Hamerling (2012), "Different Tales from Different Countries: A First Assessment of the OECD 'Adaptation Marker', Germanwatch Briefing Paper, Germanwatch, Bonn; Terpstra, P. et al. (2013), "The pumbling of adaptation finance: accountability, transparency and accessibility at the local level", WRI Working Paper, WRI, Washington DC; OECD-CPI (2015), Climate Finance in 2013-14 and the USD 100 billion goal: A report by the OECD in collaboration with the Climate Policy Initiative, OECD Publishing, Paris.

31. The integration of adaptation into broader development co-operation activities is important given that the World Bank estimated that up to 40\% of ODA is sensitive to climate risks (World Bank, 2006). For example, energy-related interventions can benefit from integrating adaptation considerations. Incorporating a solar photovoltaic (PV) system into an energy project can, for instance, increase resilience to climate extremes such as storms, droughts or high temperatures, as solar PV can continue to operate under these conditions while conventional power sources and their transmission to end-users are negatively affected (e.g. hydropower dams that depend on rainfall; thermal power stations that require water for cooling; above-ground power transmission systems that are exposed to storm damage). 
32. In addition to bilateral sources of finance, multilateral institutions and development banks also provided climate-related development finance targeting adaptation. Between 2013 and 2014, this finance averaged USD 5.5 billion per annum, from which USD 3.9 billion was ODA and the remainder other official flows (see Figure 2). This is equivalent to $18 \%$ of total climate-related official development finance. The top sectors targeted by multilateral climate-related finance in 2014 were agriculture (USD 1.8 billion; 38\% of adaptation ODA), followed by general environment protection (USD 1 billion; 21\%), humanitarian aid and developmental food aid (USD 830 million or 17\%), water supply and sanitation (USD 693 million; 14\%), and transport and storage (USD 181 million; 4\%).

Figure 2: Bilateral and multilateral adaptation-related development finance in 2013 and 2014

Bilateral and multilateral ODA and other official flow commitments, USD billion, annual average, constant 2013 prices

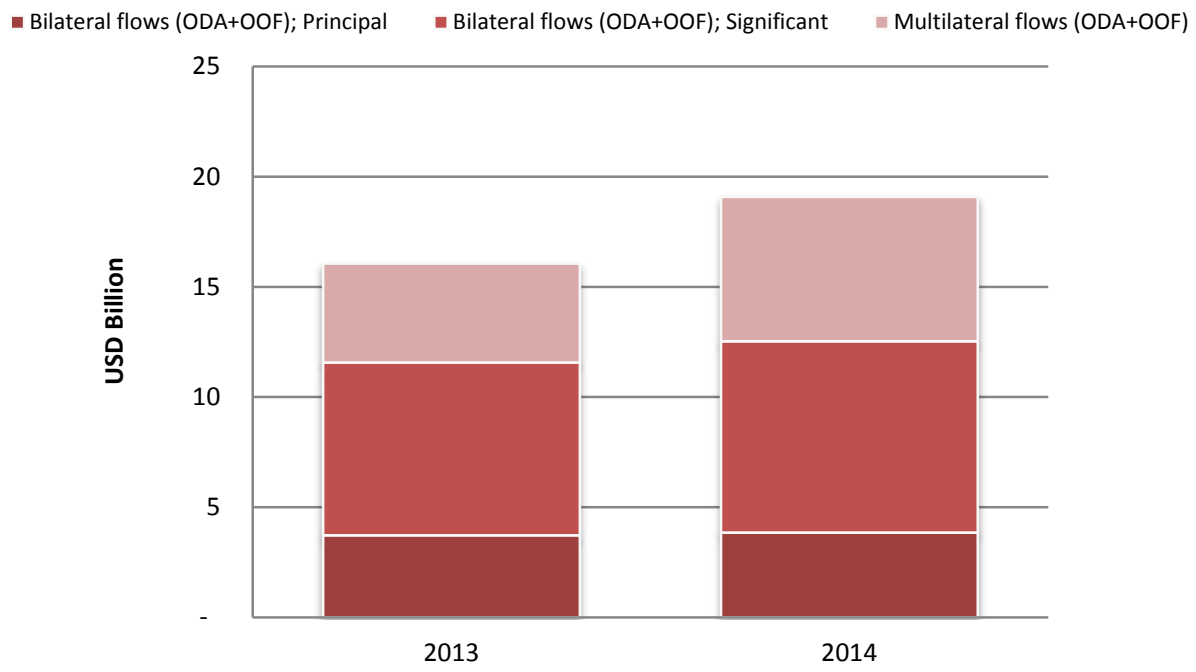

Source: OECD (2016) Creditor Reporting System

Note: Data for adaptation-related commitments from multilateral institutions is only available from 2013 onwards. However, multilateral institutions have been funding adaptation for much longer. Some multilateral flows are Rio-marked using the climate component only because their amounts marked as significant are relatively small.

33. Finally, at national level, developing countries sometimes have climate change funds to leverage finance. These funds draw on international, national and other domestic sources of finance, and they pool finance to manage climate-related activities programmatically (e.g. in Bangladesh, Ethiopia, Indonesia and Rwanda, see Kaur et al., 2015; with Cambodia and Tanzania considering this option). National development banks are also increasing their role as intermediaries in funding climate change adaptation activities in-country (Smallridge et al., 2012). These banks can access both national and international sources of public and private capital, deploy a range of financial instruments (e.g. risk finance), can target high-risk investments, and provide finance to local actors (e.g. India, Rwanda, Bangladesh; Kaur et al., 2015). Countries are also integrating climate considerations into financial planning systems (e.g. Bangladesh, Cambodia, Nepal, Indonesia; Kaur et al., 2015). This helps raise and tap domestic revenues, incentivise adaptation-related expenditures (e.g. through carbon taxes earmarking the revenue raised to fund adaptation-related activities, adaptation-related tax exemptions); it also promotes finance predictability and sustainability (e.g. budget codes providing policy direction).

34. Notwithstanding these activities to financially mainstream adaptation in developing countries, they face considerable challenges in accessing and co-ordinating their approach to financing climate action. This challenge is aggravated by the proliferation of bilateral and multilateral, public and private, national and international financing instruments and mechanisms each with different requirements and 
procedures for access (CDKN, 2013; CIFs, 2014; Kato and Ellis, 2016). It also has to do with low levels of awareness in developing countries about the risks of climate change and the possible adaptation solutions; few consistent sources of information to find out more about climate change risks, adaptation needs and concerns; an insufficient set of adaptation project pipelines coming from countries; and low levels of understanding of the procedures to access available climate change funding (e.g. OECD 2015b).

\section{The climate-development nexus: integrating development and adaptation planning at national level}

35. Adaptation activities may be planned by national or sub-national governments, or undertaken autonomously by private actors. Many adaptation actions are autonomous, but governments are responsible for the adaptation of climate-sensitive public assets and services (CCCD, 2010). For example, this includes public policy for adaptation to boost the climate resilience of key publicly owned infrastructure such as schools, hospitals, roads and water sanitation facilities, as well as policies aiming to "climate proof" systems that provide essential public services such as clean water and health care. Governments also influence autonomous adaptation responses of others through policies, regulations and public goods, such as incentives for efficient water use, building regulations, and early warning systems (Hellmuth et al., 2007; OECD, 2009).

36. According to McGray et al. (2007), there are two types of adaptation activities that governments can pursue. First, adaptation can consist of discrete activities undertaken in response to climate risks across sectors. Such an "impact focus" describes actions targeted at specific climate hazards (e.g. community relocation due to sea level rise) (McGray et al., 2007). Second, adaptation may be conceptualised as a developmental challenge and have a "vulnerability focus" (McGray et al., 2007; African Union, 2013). This focus describes conventional development strategies which are not targeted at increasing resilience but that can support adaptation, such as poverty reduction, community health care, education, provision of infrastructure and basic services (Tanner and Horn-Phathanothai, 2013). A vulnerability focus is often understood as climate-resilient development. Between both foci are actions that affirm development and adaptation priorities (e.g. building adaptive capacity, managing climate risk) (McGray et al., 2007). UNFCCC sources of adaptation finance have tended to focus on the "impact focus", while development co-operation providers have tended towards the "vulnerability focus" (Tanner and Mitchell, 2008; Tanner and Horn-Phathanothai, 2013). In practice, the integration of climate change adaptation in development, or in environmental or disaster risk reduction objectives, policies and programmes has progressed slowly (Tanner and Horn-Phathanothai, 2013), although the pace of activity is increasing (Helgeson and Ellis, 2015).

\subsection{Mainstreaming climate change adaptation in national development planning}

37. National scale planning for adaptation and development is a central part of an effective response to climate change in developing countries, but the success will depend upon implementation at the sectoral and sub-national levels:

- Cross-sectoral national adaptation and development planning requires approaches to collaborate, identify and effectively integrate priorities across a wide-range of sector ministerial functions, actors and other relevant stakeholders (e.g. local communities and private sector actors). The entry points for integrating adaptation in national development planning are greatest when developing country governments take a comprehensive perspective to set ambitious social and economic objectives beyond poverty reduction and economic growth at the national level to also recognise linkages with sector-level policy objectives and with local development and well-being objectives. 
- Sub-national perspectives will often revolve around opportunities for employment and sustainable livelihoods, as well as provision of clean water and air, sanitation, health care and education services.

39. In order to gain an initial snapshot of the extent to which adaptation is integrated in national development planning, we took the national development plans of 15 countries that are high recipients of bilateral adaptation-related development finance. We then did a word search for adaptation-related terms to identify where and to what extent adaptation considerations featured in the planning document. The presence of adaptation-related terms in national development plans was taken as a proxy for mainstreaming. This approach provides an initial picture of mainstreaming in these countries and can be replicated to other countries in future work. Similarly, future work could use this paper's findings as starting point to study individual countries more in-depth. However, there are also a number of caveats to this approach that need to be highlighted. First, is that countries may differ in how much detail they included on adaptation in their development plan, particularly if they have a separate adaptation plan. Second, there may be a number of other initiatives related to the integration of adaptation into development planning (especially at sectoral and local level) that are not captured in the two types of plans studied here and which are therefore not reflected in our results. Third, actual implementation of national development plans varies across countries; the integration of adaptation considerations into the planning document is not a guarantee that mainstreaming played out in practice. Fourth, there is also a temporal challenge, given the large amount of time and resources a national development plan can take to produce. Some of these plans date back to 2010 and one to 2006. There may therefore have been progress in the integration of adaptation in national development planning since the publication of these plans.

40. The 15 countries were selected on the basis of bilateral adaptation-related development finance flows, as captured by the adaptation "Rio marker" in the OECD DAC CRS (see Box 3). All recipient countries were broken down into geographic regions (North and Sub-Saharan Africa, Central and South America, Far East and South and Central Asia, and Oceania). Within these regions, countries were ranked by total volume of adaptation-related ODA received over 2011-13, and by adaptation-related ODA as a share of total ODA received over this period. Countries that were high recipients in both absolute and relative terms in each region were then selected for analysis (see Table 2). Together, these 15 countries account for $29 \%$ of bilateral adaptation-related ODA commitments over 2010-14. Some coincide with the countries that have already taken steps to launch a NAP process domestically (Bangladesh, Bolivia, Cambodia, India, Indonesia, Tanzania, and Viet Nam).

41. For each country, the most recent national development plan was identified (in English, French or Spanish, otherwise the English translation was used). A word search to find adaptation-related areas in the plan was then used, using the words and word fragments "adapt", "climat" and "resilien". Additionally, all environment-related chapters in national development plan chapters were analysed. Three categories emerged using this methodology (see also Table 2):

- Adaptation and related notions are widely integrated throughout the plan, in a wide variety of sectors, and is mentioned frequently and in detail (the "green" countries in Table 2);

- Adaptation and related notions are discussed in some detail, mainly in the section on environment and climate change, but they are also acknowledged and linked to the discussions in some of the sectors (the "yellow" countries in Table 2); and

- Adaptation and related notions are not mentioned, or are mentioned only very briefly in the plan. They are mentioned within the context of environment and climate change, and are referred to in few, if any, other sectors (the "red" countries in Table 2). 
Table 2. The extent to which climate change adaptation is integrated into national development plans in select countries: synthesis ${ }^{4}$

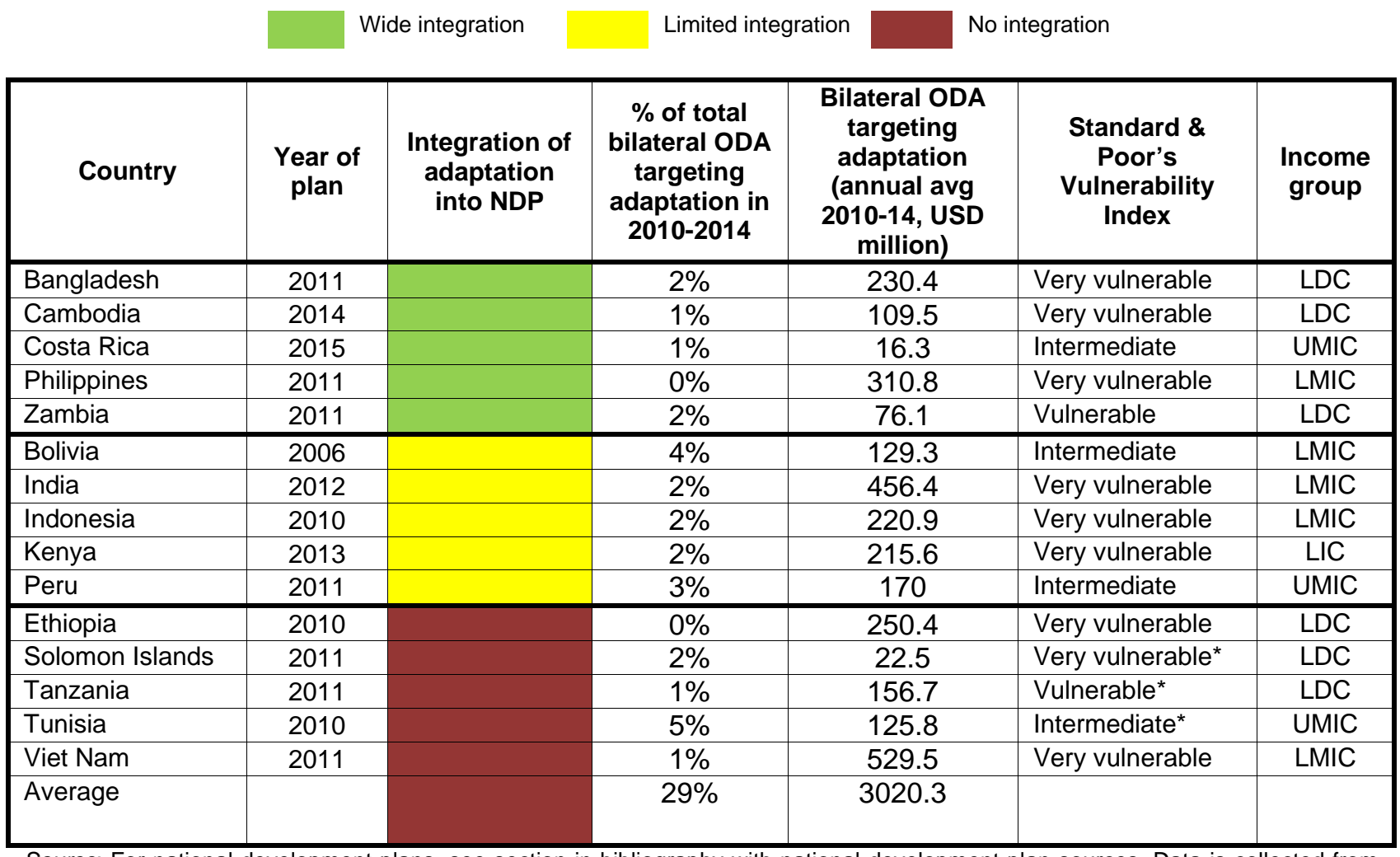

Source: For national development plans, see section in bibliography with national development plan sources. Data is collected from the OECD DAC Creditor Reporting System. Vulnerability is taken from the Standard and Poor's climate vulnerability index, found at Standard and Poor's, "Climate Change is a Global Mega-Trend for Sovereign Risk", https://www.globalcreditportal.com/ratingsdirect/renderArticle.do?articleld=1318252\&SctArtld=236925\&from=CM\&nsI code=LIME\&so urceObjectld=8606813\&sourceRevld=1\&fee ind=N\&exp date=20240514-20:34:43, accessed 1 June 2015 . Countries marked with an asterisk $\left(^{\star}\right)$ were not included in the Standard and Poor's index, therefore the vulnerability has been determined by looking at Maplecroft's Climate Vulnerability Index: Maplecroft (2014), Climate Change Vulnerability Index 2014.

42. Climate change is mentioned in each of the national development plans examined, and adaptation in all but one (Tunisia), indicating that the link between climate change and development is recognised by national decision makers in all countries studied. However, the degree of sectoral integration varies considerably (as illustrated by the green-yellow-red categorisation in Table 2). To give some illustrative examples:

- $\quad$ The Philippines was placed in the green category, as The Philippine Development Plan 20112016 explicitly integrates climate change adaptation concerns into seven of its ten chapters, including on inclusive growth, services and industry, infrastructure, social development, and peace and security (Republic of the Philippines, 2011);

- $\quad$ Peru was placed in the yellow category, as while its adaptation programme is detailed, and adaptation is one of Peru's five environmental priorities, it is only mentioned in the sections of the national development plan on environmental management and on agriculture, suggesting that adaptation is predominantly treated through the lens of environmental policy or as an environmental issue rather than as a core development issue.

These differences may reflect genuine differences in the practice across countries, but also perhaps simply differences in the way the documents are written. For example, where a national adaptation plan exists, 
then this may provide the detail while the treatment in the development plan is cursory to the adaptation planning exercise.

43. There was a higher degree of variation across countries where adaptation is not mentioned in the plan, or is mentioned very briefly (the "red" category in Table 2) than with other countries:

- Tunisia’s national development plan does not mention adaptation, and makes only one reference to climate change.

- Viet Nam, while explicitly mentioning climate change adaptation, only touches very briefly upon the subject in the plan, in the paragraph on the environment and in another on rural and urban development.

- In the case of Tanzania, adaptation is explicitly recognised as important for sustainable economic growth, but the subject is predominantly treated in the section on environment and climate change, with a focus on establishing a national institutional and financial framework for climate change. Climate risks and solutions are briefly acknowledged, but only in sections on agriculture and water.

44. From this analysis, no other discernible features distinguish countries across the three identified categories. As Table 2 illustrates, each of the three groups contains countries ranging from LDCs to Upper Middle Income Countries (UMICs), and from "very vulnerable" to "intermediate" vulnerability to climate change (Maplecroft, 2013; Standard and Poor's, 2015). On average, the year of publication of the national development plans is slightly more recent for countries where adaptation is mentioned (2012 on average in the "green" category) than the other two categories (2010 in the "yellow" category and 2011 in the "red" category). The share of total bilateral ODA targeting adaptation is also slightly higher in the category of countries that include adaptation in their national plans, and is smaller in the other two categories (the share was $17 \%$ for countries in the "green" group, $15 \%$ for those in the "yellow" group and $12 \%$ for those in the "red" category). Interestingly, four of the countries have benefited from the PPCR programme (Bangladesh, Bolivia, Cambodia and Zambia) and all but one of these are in the "green" category, which suggests that PPCR may be helping to strengthen mainstreaming processes in-country.

45. Overall, our findings suggest that high vulnerability to climate change, and/or an important provider focus on climate change adaptation in a partner country alone does not guarantee adaptation mainstreaming into national development planning. Rather, experience from other communities, such as the biodiversity, illustrates that mainstreaming environmental issues into core policy documents, sector and finance ministries, programmes and projects is driven by a number of factors. Notably successful mainstreaming requires: (a) time; (b) leadership from "champions" of the issue; (c) a convincing evidencebase founded on scientific and socio-economic data; (d) effective multi-stakeholder engagement and communication; (e) alignment with core government priorities; and (f) a robust monitoring and evaluation framework (Carmin et al. 2013; Huntley and Redford, 2014; Drutschinin, et al., 2015).

\subsection{Exploring linkages in national planning between adaptation and selected themes: ecosystems, poverty and livelihoods, urban and rural development}

46. The second part of this analysis looked at the linkages between countries' national development and climate change plans, on the one hand, with three selected themes, on the other hand:

1. Livelihoods and poverty reduction: the link with livelihoods and poverty reduction was explored because poor people are likely to be the most vulnerable to the impacts of climate change, particularly as they are often located in areas highly exposed to hazards linked to climate change 
(e.g. in flood plains) and their livelihoods may be highly dependent on natural resources and ecosystem services that are also at risk from climate change. The poor typically lack the technical and financial capacity to cope with the impacts of a changing climate on their environment (GIZ, 2012; Drutschinin et al., 2015; Reid, 2015).

2. Rural and urban development: the link with rural and urban development was analysed to understand to what extent adaptation actions are being tailored to local conditions. Rural areas are important for subsistence and for the economy of many developing countries; for example, over $50 \%$ of the population of Africa and of Asia lives in rural areas (United Nations, 2014) and the value-added from agriculture comprised an average of $26 \%$ of the GDP of low income countries in 2013 (World Bank, 2015). By contrast, over the last decades there has been a major and accelerating global trend of increasing urbanisation, with the main source of change located in developing countries; in 2014, 54\% of the world's population was living in urban areas (United Nations, 2014). While Latin America and the Caribbean is one of the most urbanised regions (80\% living in urban areas in 2014), Asia and Africa have the fastest rates of urbanisation (United Nations, 2014), making this an important consideration for adaptation planning in all developing countries.

3. Biodiversity and ecosystem services: the link with biodiversity and ecosystem services, and more specifically ecosystem-based adaptation, is explored as this is an area of growing international attention by both the environment and development co-operation communities, due to its potential to deliver a range of social, economic and environmental benefits at a lower cost than man-made infrastructure (Box 4). As the term "ecosystem-based adaptation" is not yet widely used in practice (Doswald et al., 2014), analysis was extended to also look for EbA-relevant activities (i.e. integrated watershed management, integrated forest management, agroforestry, conservation agriculture, coastal forestation and coral reef protection).

47. Additionally, the analysis considered sections or sub-sections of the plans focusing on rural and urban development, agriculture, forests, water, natural resources and environment, as well as any section dedicated to adaptation (in the climate change plans). These linkages led to three categories:

- The link with adaptation is explicit (“dark blue” category in Tables 3 and 4);

- The link with adaptation is implicit. For rural development, when adaptation was linked with agriculture, but not with rural development more broadly, light blue was attributed ("light blue" category in Tables 3 and 4); and

- The issue is not associated to adaptation, or not discussed at all ("white” category in Tables 3 and 4).

48. To further structure the analysis, each plan was then given a score (ranging from 0 to 4 , calculated by assigning 1 point to each "dark blue" box, 0.5 points for each "light blue" box, and 0 points for a "white" box, and summing the scores across the four boxes per plan in Tables 3 and 4). Higher scores are obtained in countries with the strongest the linkages across the four themes. Countries in these tables are listed in the same order as in Table 1 to show how these results relate to the degree of integration of adaptation into national development plans. For the 15 countries, there appears to be a possible relation between countries classified in the high and medium levels of integration and the degree of adaptation thematic linkages in national development plans. Table 3 also suggests a possible pattern of more recognition of these particular themes in national development planning of countries that have taken steps in launching the NAP process - Bangladesh, Bolivia, Cambodia, India, Indonesia, Tanzania, and Viet Nam - though there are some exceptions. Table 4 shows a much broader level of adaptation-relevant thematic 
linkages in the climate change plans, however these connections are not systematically carried forward in development plans, particularly for those countries where adaptation is only weakly integrated into development planning. Annex 2 provides a fuller description of these results for each country.

\section{Box 4. Ecosystem-based adaptation}

Ecosystem-based adaptation (EbA) is defined by the Convention on Biological Diversity as "the use of biodiversity and ecosystem services to help people adapt to the adverse effects of climate change as part of an overall adaptation strategy" (CBD, 2009). A review of EbA-related interventions showed that the majority (63\% in the peerreviewed literature, $85 \%$ in the grey literature) have brought multiple social, economic and environmental benefits; while only $6 \%$ in the peer-reviewed literature found negative impacts associated with EbA - the rest were ambiguous (Doswald et al., 2014). From a cost-benefit perspective, TEEB (2009) has argued that ecosystem-based solutions are cheaper than man-made infrastructure, although more studies comparing the costs and benefits of EbA versus hard infrastructure approaches are required (Doswald et al., 2014).

Providers of development finance are increasingly recognising the importance of the nexus between biodiversity and adaptation. Over 2010-14, members of the OECD DAC committed an average of USD 2.8 billion of bilateral ODA per year to target adaptation and biodiversity objectives together, representing $29 \%$ of total adaptation-related bilateral ODA and $49 \%$ of total biodiversity-related bilateral ODA (OECD DAC CRS, 2016). Turning to multilateral finance, the GEF noted ecosystem-based approaches in coastal areas in its Strategy on Adaptation to Climate Change 2010-2014 (GEF, 2011), and has subsequently identified ecosystem-based adaptation as one of the three "emerging mechanisms and areas for innovation" in its Strategy on Adaptation to Climate Change 2014-2018 (GEF, 2014).

Despite the increasing international focus on EbA approaches, the evidence about what works, what does not and conditions for success remains thin (Reid, 2015; Doswald et al., 2014). It has also been challenging to scale up EbA beyond small-scale and pilot projects (Reid, 2015; Midgley et al., 2012). One recommendation that emerges from the literature is to better link EbA with national and sub-national institutional, governance and policy frameworks (Reid, 2015; Midgley et al., 2012). By looking at the linkages between adaptation, biodiversity and ecosystem services in national planning, and the linkages between adaptation and sub-national governance, both urban and rural, this study provides an initial snapshot of the state of play across the 15 countries.

Source: CBD (2009), Connecting biodiversity and climate change mitigation and adaptation: Report of the second ad hoc technical expert group on biodiversity and climate change (CBD Technical Series No. 41). Montreal: Secretariat of the Convention on Biological Diversity; Doswald, et al. (2014) 'Effectiveness of ecosystem-based approaches for adaptation: review of the evidence-base' Climate and Development; GEF (Global Environment Facility) (2014), GEF Programming Strategy on Adaptation to Climate Change: Least Developed Countries Fund and the Special Climate Change Fund, GEF Secretariat, October 2014, Washington D.C.; GEF (2011), Strategy on Adaptation to Climate Change for the Least Developed Countries Fund (LDCF) and the Special Climate Change Fund (SCCF), GEF Secretariat, May 2011, Washington D.C.; Midgley, G., Marais, S., Barnett, M. and Wagsaether, K. (2012), "Biodiversity, Climate Change and Sustainable Development - Harnessing Synergies and Celebrating Successes, Final Technical Report" South Africa National Biodiversity Institute, Conservation South Africa and Indigo, January 2012; Reid, H. (2015), "Ecosystem- and community-based adaptation: learning from community-based natural resource management", Climate and Development.

49. Tables 3 and 4 illustrate that the linkages between adaptation and livelihoods and poverty reduction, biodiversity and ecosystem services, rural development and urban development are being made more frequently and explicitly in the national climate change plans (average score is 3.6 across all countries) than in the national development plans of the 15 countries (average score is 2.5 across all countries). Countries with more recent national climate plans tend to establish these linkages more strongly.

50. Climate change adaptation is either implicitly or explicitly linked with livelihoods and poverty reduction in thirteen national development plans, and all the of fifteen national climate change plans, illustrating that the link is widely recognised by all the countries in this study. The plans recognise that climate change will impact the natural resources and sectors that the poor depend upon for survival, such as forests, water and agriculture, and that therefore adaptation to climate change is important for livelihoods and poverty reduction. The Ethiopian National Development Plan (Federal Democratic Republic of Ethiopia Ministry of Finance and Economic Development, 2010) also recognises that infrastructure such as roads and dams are important for poverty reduction, and that these must be made 
climate resilient. At least seven countries highlight the development of alternative livelihoods or livelihood diversification as an adaptation measure, focusing in particular on eco-tourism but also on other naturebased enterprises such as bee-keeping. Some countries such as Bolivia, Cambodia and Indonesia focus on the engagement of vulnerable local communities in implementing adaptation measures, such as sustainable forest management and mangrove planting (see bibliographical section on national development plans and climate change plans for full list of references). Additionally, Bangladesh, Cambodia, India, Indonesia, Kenya and the Philippines tie vulnerability to climate change and adaptation actions explicitly to gender and empowering women, and Bangladesh, Cambodia, Costa Rica, India, Indonesia, the Solomon Islands and Zambia highlight the links between climate change adaptation and health, particularly for poor, vulnerable populations. These examples illustrate a strong connection between livelihoods and poverty reduction and biodiversity and other ecosystem services from natural resources.

Table 3. Adaptation thematic linkages in national development plans

\begin{tabular}{|c|c|c|c|c|c|c|}
\hline Country & $\begin{array}{l}\text { Year of } \\
\text { NDP }\end{array}$ & $\begin{array}{l}\text { Biodiversity \& } \\
\text { Ecosystems }\end{array}$ & $\begin{array}{c}\text { Livelihoods \& } \\
\text { Poverty Reduction }\end{array}$ & Rural Dev & Urban Dev & Score \\
\hline Bangladesh & 2011 & & & & & 4 \\
\hline Cambodia & 2014 & & & & & 2.5 \\
\hline Costa Rica & 2015 & & & & & 3.5 \\
\hline Philippines & 2011 & & & & & 4 \\
\hline Zambia & 2011 & & & & & 3.5 \\
\hline Bolivia & 2006 & & & & & 3.5 \\
\hline India & 2012 & & & & & 3 \\
\hline Indonesia & 2010 & & & & & 2.5 \\
\hline Kenya & 2013 & & & & & 2.5 \\
\hline Peru & 2011 & & & & & 3 \\
\hline Ethiopia & 2010 & & & & & 2 \\
\hline Solomon Islands & 2011 & & & & & 2 \\
\hline Tanzania & 2011 & & & & & 1.5 \\
\hline $\begin{array}{l}\text { Tunisia (5 year } \\
\text { plan) }\end{array}$ & 2010 & & & & & 0.5 \\
\hline $\begin{array}{l}\text { Tunisia (New } \\
\text { Tunisia Strategy) }\end{array}$ & 2012 & & & & & 1 \\
\hline Viet Nam & 2011 & & & & & 1.5 \\
\hline
\end{tabular}

Source: See section on national development plans in bibliography for a full list of national development plans

51. The linkages between biodiversity, ecosystems and adaptation are more frequent and explicit in the national climate change plans than in the development plans, with all of the national climate change plans making reference to at least one ecosystem-based adaptation relevant measure (Table 4). Indeed, only four of the 15 countries studied explicitly used the term "ecosystem-based adaptation", or a similar phrase such as "ecosystem-based management” or "ecosystem-based approaches": Cambodia, Costa Rica, Kenya and the Philippines. Stronger linkages were found when the word search was extended to include specific sector themes for EbA, namely integrated watershed management, integrated forest management, agroforestry, conservation agriculture, coastal forestation and coral reef protection.

52. EbA-relevant approaches were predominantly described in the forest sector. Almost all countries mention afforestation and reforestation programmes (11 out of 15 national development plans, 13 out of 15 climate change plans), and seven climate change plans mention coastal forestation as an adaptation measure (e.g. planting mangroves), at least two climate change plans mention agroforestry, and at least three climate change plans explicitly link forests with integrated watershed management. After afforestation and reforestation-type measures, the areas of focus for EbA-relevant measures were agriculture (e.g. conservation agriculture), watersheds (e.g. integrated watershed management), and coastal 
areas (e.g. planting mangroves, protecting and rehabilitating coral reefs); these were each mentioned in about half of the national development plans and national climate change plans. Other areas of focus found with less frequency were the conservation and rehabilitation of wetlands and broader sustainable land management. These results - demonstrating recognition in about $50 \%$ of the selected country group - are broadly in line with those of Doswald et al. (2014) in their review of EbA-relevant measures from the scientific and grey literature. Finally, EbA-relevant measures appeared to be almost exclusively concentrated in rural areas, with almost no explicit mention of links to urban areas. Only Zambia mentions an urban EbA-relevant measure in its climate change plan, i.e. creating green spaces in urban centres to moderate temperatures. And only Viet Nam links EbA-relevant measures in rural areas to adaptation in urban areas in its climate change plan, in particular citing green belts linked to flood prevention in cities.

Table 4. Adaptation thematic linkages in climate change plans

\begin{tabular}{|c|c|c|c|c|c|c|}
\hline Country & $\begin{array}{l}\text { Year of } \\
\text { CCP }\end{array}$ & $\begin{array}{c}\text { Biodiversity \& } \\
\text { Ecosystems }\end{array}$ & $\begin{array}{c}\text { Livelihoods \& } \\
\text { Poverty Reduction }\end{array}$ & Rural Dev & Urban Dev & Score \\
\hline Bangladesh & 2009 & & & & & 4 \\
\hline Cambodia & 2013 & & & & & 3.5 \\
\hline Costa Rica & 2009 & & & & & 3 \\
\hline Philippines & 2011 & & & & & 4 \\
\hline Zambia & 2010 & & & & & 4 \\
\hline Bolivia & 2009 & & & & & 2.5 \\
\hline India & 2008 & & & & & 3.5 \\
\hline Indonesia & 2007 & & & & & 3.5 \\
\hline Kenya & 2013 & & & & & 3.5 \\
\hline Peru & 2014 & & & & & 4 \\
\hline Ethiopia & 2011 & & & & & 3.5 \\
\hline Solomon Islands & 2012 & & & & & 3.5 \\
\hline Tanzania & 2012 & & & & & 4 \\
\hline Tunisia & 2012 & & & & & 3.5 \\
\hline Viet Nam & 2011 & & & & & 3.5 \\
\hline
\end{tabular}

Source: See section of bibliography for climate change plans

53. The link between climate change adaptation and rural development is recognised to some extent in 11 of the national development plans, and in all 15 of the national climate change plans. Making rural infrastructure climate-resilient, such as road infrastructure, dams and irrigation is highlighted by at least six countries, and making agriculture climate-resilient is emphasised by at least eight countries. However, fewer countries explicitly mention the integration of adaptation considerations into rural development policy and planning. Peru and Zambia are the only countries that treat this issue in detail; Peru highlights the need to integrate adaptation into regional, territorial and local policies, planning and management, while Zambia mentions integrating adaptation into district plans, performing vulnerability assessments at the district level, and developing rural climate change action plans. The Solomon Islands and Tunisia also treat this issue to a lesser degree: the Solomon Islands note the importance of performing risk reduction and vulnerability assessments of rural communities in order to inform adaptation actions; Tunisia emphasises that new rural developments should avoid areas at high risk to climate change impacts.

54. Links between adaptation and urban development were recognised more frequently than rural development themes, with the greatest recognition of these links being made in climate change plans. The result in Tables 3 and 4 show explicit or implicit linkages for urban adaptation in twelve out of the fifteen countries' national development plans, and explicitly in fourteen of the fifteen national climate change plans. The lack of a link between urban development and adaptation in Bolivia's national climate change plan is not surprising, since their climate change strategy focuses on forests and is therefore more focused 
on rural areas. As a rule, countries highlight the need to make infrastructure climate-resilient, with a particular focus on housing and on transport and water infrastructure. There does not appear to be a focus on retrofitting buildings and infrastructure, but rather on ensuring that any new infrastructure takes climate change into account. A common measure mentioned by at least eight countries is the integration of adaptation measures into building codes, regulations and norms, while Bangladesh and Cambodia focus more broadly on integrating climate resilience into urban planning. Bangladesh, Costa Rica, Indonesia and Kenya highlight a particular focus on flood prevention and control hence highlighting the connection to disaster risk management.

\subsection{Further observations}

55. In reading through the plans, a number of observations can be made regarding governance and finance. With respect to governance and institutional measures to champion mainstreaming, some countries have developed an inter-ministerial climate change committee or an expert climate change commission to co-ordinate national climate change responses, including Bangladesh, Cambodia, Peru, Philippines, Tanzania, Zambia. This may help to explain some of the strong results in the first review for at least a subset of these countries - Bangladesh, Cambodia, Philippines and Zambia - all of which show strong progress in recognising adaptation in their national development plans. Interestingly most of the national development plans and climate change plans also have a section on climate change adaptation awareness raising, reporting on measures targeting the general population and policy makers alike, as well as actions in the education arena aiming to build capacity and skills for adaptation. These activities help to build awareness and knowledge, which in turn is needed to underpin action on adaptation.

56. In the area of finance, there are a number of emerging developments in domestic arrangements and resource mobilisation that may be useful to explore further. The Addis Ababa Agenda for Action recognises the key role of domestic resource mobilisation to deliver sustainable development, alongside international public development finance (e.g. ODA) and private finance. As creation of these mechanisms is recent, there is little understanding of their effectiveness to promote good outcomes. Measures in some countries are generating domestic resources or identifying funding sources beyond ODA, with relevant examples being payments for ecosystem services, accessing carbon markets, environmental taxation, debtfor-adaptation swap.

\section{Conclusions}

57. A number of international mechanisms exist to support developing countries to adapt to a changing climate and avert potentially devastating climate change. The UNFCCC is active in this space, with initial actions dating back to the early 2000s. Key international commitments are to support LDCs in the development of NAPAs and NAPs, to develop and maintain a number of financial mechanisms to support developing countries through the GEF or the GCF. Bilateral and multilateral providers of development co-operation offer financial and technical support to developing countries for adaptation and are increasingly honouring commitments to increase international public finance for adaptation. In 2014, bilateral and multilateral providers committed close to USD 19 billion development finance flows for adaptation-related interventions. Much of this finance is focusing on ensuring that climate change adaptation is integrated in the core of national development planning and policies, which ultimately ought to guide the development pathway and investment patterns in individual developing countries. In turn, strategic recognition of climate change adaptation priorities in the context of development planning, can guide development co-operation efforts and improve the targeting and effectiveness of programming in this area.

58. A key question is how adaptation planning and understanding of climate change in country is being translated into higher levels of adaptation and related mainstreaming in national development 
strategies and plans. This paper provides a first answer and preliminary insights into this question, with a focus on a selection of countries. The paper reviews the adaptation-related international landscape (mandates, institutions, financial arrangements and flows), in particular looking for available tools and mechanisms at the international level that could help foster the mainstreaming of adaptation into development planning. The paper looks at national-level mainstreaming processes of adaptation in development plans in 15 developing countries. Progress in mainstreaming is defined here at the level of a national government achieving recognition of climate change adaptation and the related notions of resilience-building or climate change risk management in strategic planning documents.

59. In this initial assessment of national development plans of 15 countries, the review found uneven recognition of adaptation and related notions in mainstream development planning documentation. The analysis organised countries into three categories of adaptation "mainstreaming" performance (high, medium, low). Performance was evenly distributed with five countries falling into each of the three categories. The paper also looked at whether and how adaptation is linking to a range of relevant development themes, notably livelihoods and poverty reduction, biodiversity and ecosystems, and urban and rural development. The findings of this second level review show a strong connection between those countries with high levels of adaptation mainstreaming and those that explicitly connect climate change risk and adaptation issues to these three policy areas.

60. Overall, the majority of the national development plans link, in one way or another, poverty reduction efforts to adaptation and to conservation of biodiversity and provision of ecosystem services. The linkages between biodiversity, ecosystems and adaptation are more frequent and explicit in particular in national climate plans than in development plans, with virtually all of the climate plans referring to ecosystem-based adaptation in at least one instance. Further, EbA-relevant approaches were predominantly found in the forest sector where there are strong and straightforward linkages to local communities, poverty reduction and ensuring poor people's livelihoods. Beyond this, the link between adaptation and rural development is widely recognised, with references found in most of development plans and in all climate plans. However linkages to adaptation and urban development themes were even more frequent than for rural development, again with the greatest recognition coming through climate plans. Overall, countries with a pattern of strong linkages in development plans to key themes related to adaptation also show adaptation to be well integrated in their development plans.

61. Of the 15 countries selected for this study, four have benefited from funding and support under the Pilot Program for Climate Resilience and three of these four countries displayed high levels of mainstreaming adaptation in development planning and policy (Bangladesh, Cambodia, and Zambia). This finding suggests that a broad programmatic approach to adaptation planning may also support the mainstreaming of adaptation into development planning, with dedicated resources for awareness raising and stakeholder engagement. This type of programme may be more effective compared to project-based finance. Our findings, in any event, are tentative but could form the basis of further research.

62. Finally, the findings of this report do not reflect an in-depth examination of the practices in development co-operation or in any one of the 15 countries selected for the review, but they do provide set of preliminary set of information to guide further work. The results can help us to understand the causes or drivers of the patterns observed in looking across countries to assess progress to mainstream adaptation in country. Further work would be required to ground-truth and to better understand what is driving these results within each of the countries. Case study analysis, for example, would complement this type of literature review to provide a richer understanding of how increased awareness and understanding can translate into action. In particular, it can provide insights into the views of key stakeholders on progress towards an integrated, effective and systematic approach towards managing climate risks. Despite these caveats, the findings provide a strong starting point for any more in-depth assessment of the challenges and opportunities associated with mainstreaming adaptation in development planning. 


\section{BIBLIOGRAPHY}

African Development Bank (AfDB) et al., (2003), Poverty and Climate Change: Reducing the Vulnerability of the Poor Through Adaptation, World Bank, Washington DC. Available online at: http://www.oecd.org/env/cc/2502872.pdf.

African Union (2013), Draft African Union Strategy on Climate Change, Addis Ababa: African Union. Available online at: http://www.un.org/en/africa/osaa/pdf/au/cap_draft_auclimatestrategy_2015.pdf.

Carmin, J., D. Dodman and E. Chu (2013), "Urban Climate Adaptation and Leadership: From Conceptual Understanding to Practical Action", OECD Regional Development Working Papers, No. 2013/26, OECD Publishing, Paris. DOI: http://dx.doi.org/10.1787/5k3ttg88w8hh-en.

Commission on Climate Change and Development (CCCD) (2010), Closing the Gaps: Disaster risk reduction and adaptation to climate change in developing countries, Report of the Commission on Climate Change and Development, Stockholm: Ministry for Foreign Affairs. Available online at: http://www.ccdcommission.org/Filer/report/CCD_REPORT.pdf.

Climate and Development Knowledge Network (CDKN) (2013), Climate Finance: Challenges and Responses, CDKN Policy Brief, Available online at: http://cdkn.org/resource/climate-financechallenges-and-responses/?loclang=en gb.

Climate Investment Funds (CIF) (2014), Learning by Doing: The CIFs Contribution to Climate Finance; Available Online: www.climateinvestmentfunds.org (accessed May 2016).

CIF (2012), Pilot Program on Climate Resilience (PPCR) Semi-Annual Operational Report, PPCR/SC.11/3.Rev.1, October 19, 2012 - Meeting of the PPCR Sub-Committee Istanbul, Turkey. Available online at: http://www.climateinvestmentfunds.org/cif/node/12499.

CIF (2009), Programming and Financing Modalities for the SCF Targeted Program, The Pilot Program for Climate Resilience (PPCR), Climate Investment Funds, July 2009. Available online at: https://www-cif.climateinvestmentfunds.org/sites/default/files/meetingdocuments/ppcr_programming_and_financing_modalities.pdf.

Convention on Biological Diversity (CBD) (2009), Connecting biodiversity and climate change mitigation and adaptation: Report of the second ad hoc technical expert group on biodiversity and climate change (CBD Technical Series No. 41). Montreal: Secretariat of the Convention on Biological Diversity. Available online at: https://www.cbd.int/doc/publications/cbd-ts-41-en.pdf.

Dalal-Clayton, B. and S. Bass (2009), The challenges of environmental mainstreaming: Experience of integrating environment into development institutions and decisions, IIED, London. Available online at: http://pubs.iied.org/pdfs/17504IIED.pdf.

Dessai, S. and E.L., Schipper (2003), "The Marrakesh accords to the Kyoto protocol: Analysis and future prospects”, Global Environmental Change, 13(2), pp.149-153. Available online at: http://dx.doi.org/10.1016/S0959-3780(02)00082-1.

Doswald, N., et al. (2014) 'Effectiveness of ecosystem-based approaches for adaptation: review of the evidence-base' Climate and Development. Available online at: http://dx.doi.org/10.1080/17565529.2013.867247. 
Drutschinin, A., Casado-Asensio, J. et al. (2015), "Biodiversity and development co-operation”, OECD Development Co-operation Working Papers, No. 21, OECD Publishing. Available online at: http://dx.doi.org/10.1787/22220518.

Eriksen, S. H. and O’Brien, K. (2007), “Vulnerability, poverty and the need for sustainable development measures”, Climate Policy 7: 337-352. Available online at:

http://dx.doi.org/10.1080/14693062.2007.9685660.

Green Climate Fund (GCF) (2015), “Green Climate Fund approves first 8 investments.” Press Release. [last accessed 6 Feb 2016, http://www.greenclimate.fund/documents/20182/38417/Green_Climate_Fund_approves_first_8_inv estments.pdf/679227c6-c037-4b50-9636-fec1cd7e8588 ]

GCF (2014), Green Climate Fund Board takes key decisions on operations and makes progress on 'Essential Eight', GCF-PA.02/14, Green Climate Fund, Incheon. Available online at: http://www.aida-americas.org/sites/default/files/GCF_Press_Release_fin_20140222.pdf.

Global Environment Facility (GEF) (2014), GEF Programming Strategy on Adaptation to Climate Change: Least Developed Countries Fund and the Special Climate Change Fund, GEF Secretariat, October 2014, Washington D.C. Available online at: https://www.thegef.org/gef/node/10957.

GEF (2011), Strategy on Adaptation to Climate Change for the Least Developed Countries Fund (LDCF) and the Special Climate Change Fund (SCCF), GEF Secretariat, May 2011, Washington D.C. Available online at: http://wwwwds.worldbank.org/external/default/WDSContentServer/WDSP/IB/2011/11/21/000386194_201111 21025414/Rendered/PDF/656890WP0GEF0A00Box365722B00PUBLIC0.pdf.

Gilbert, L. et al. (2010), “Adapting to Climate Change: Why Adaptation Policy is More Difficult than We Think (and what to do about it)", Wisconsin Initiative on Climate Change Impacts, Adaptation Working Group Report, available online at: http://www.wicci.wisc.edu/report/Adaptation.pdf

GIZ (Deutsche Gesellschaft fur Internationale Zusammenarbeit) (2012) "Ecosystem-based Adaptation (EbA): A new approach to advance natural solutions for climate change adaptation across different sectors”, Factsheet, August 2012, Deutsche Gesellschaft fur Internationale Zusammenarbeit (GIZ) GmbH, Eschborn. Available online at: http://www.thai-germancooperation.info/admin/uploads/publication/5b617619d1d60fb9d845036817f53fbden.pdf.

Government of Ethiopia (2007), Climate Change National Adaptation Programme of Action of Ethiopia, Ministry of Water Resources, Addis Ababa. Available online at: http://unfccc.int/resource/docs/napa/eth01.pdf.

Government of Kenya (2013), National Climate Change Action Plan (2013-2017), Ministry of Environment and Mineral Resources, Nairobi. Available online at: http://cdkn.org/wpcontent/uploads/2013/03/Kenya-National-Climate-Change-Action-Plan.pdf.

Griggs, D. et al., (2013), “Sustainable development goals for people and planet”, Nature 395: 305-307. Available online at: http://www.nature.com/articles/495305a.

Helgeson, J. and J. Ellis (2015), "The role of the 2015 agreement in enhancing adaptation to climate change", OECD/IEA Climate Change Expert Group Papers, No. 2015/01, OECD Publishing, Paris. Available online at: http://dx.doi.org/10.1787/5jrxg3xb0h20-en. 
Hellmuth, et al. (eds.) (2007), Climate Risk Management in Africa: Learning from Practice, International Institute for Climate and Society (IRI), Columbia University, New York. Available online at: https://iri.columbia.edu/wp-content/uploads/2013/07/Climate-and-Society-No1_en.pdf.

Huntley, B.J. and Redford, K.H. (2014). 'Mainstreaming biodiversity in Practice: a STAP advisory document’. Global Environment Facility, Washington, DC. Available online at: https://www.thegef.org/gef/node/10807.

Huq, S. and H. Reid (2005), “Mainstreaming adaptation into development”, IDS Bulletin 35(3): 15-21. Available online at: http://www.ids.ac.uk/publication/climate-change-and-development1.

Intergovernmental Panel on Climate Change (IPCC) (2014), Climate Change 2014: Synthesis Report, Cambridge University Press, Cambridge. Available online at: http://www.ipcc.ch/report/ar5/syr/.

IPCC (2007), Climate Change 2007: Synthesis Report. An Assessment of the Intergovernmental Panel on Climate Change, Cambridge University Press, Cambridge. Available online at: https://www.ipcc.ch/pdf/assessment-report/ar4/syr/ar4_syr.pdf.

IPCC (2001), Climate Change 2001: Synthesis Report. A Contribution of Working Groups I, II and III to the Third Assessment Report of the Intergovernmental Panel on Climate Change, Cambridge University Press, Cambridge. Available online at: https://www.ipcc.ch/pdf/climate-changes2001/synthesis-syr/english/front.pdf.

Junghans, L. and S. Hamerling (2012), "Different Tales from Different Countries: A First Assessment of the OECD ‘Adaptation Marker’”, Germanwatch Briefing Paper, Germanwatch, Bonn. Available online at: http://germanwatch.org/fr/download/7083.pdf.

Kato, T. and J. Ellis (2016), "Communicating Progress in National and Global Adaptation to Climate Change", OECD/IEA Climate Change Expert Group Papers, No. 2016/01, OECD Publishing, Paris. Available online at: http://www.oecd.org/environment/cc/Adaptation-Communication-CCXG-paper2016(1).pdf.

Kato, T. et al. (2014), "Scaling up and replicating effective climate finance interventions”, OECD/IEA Climate Change Expert Group Papers. Available online at: http://dx.doi.org/10.1787/5js1qffvmnhken.

Kaur, N. et al. (2015), “Financing radical adaptation”, IIED Briefing, London, IIED. Available online at: http://pubs.iied.org/pdfs/17269IIED.pdf.

Maplecroft (2014), Climate Change Vulnerability Index 2014. Available Online at: https://maplecroft.com/themes/cc.

McGray, H. et al. (2007), Weathering the Storm: Options for Framing Adaptation and Development, World Resources Institute, Washington D.C. Available online at: http://pdf.wri.org/weathering the storm.pdf.

Mickwitz, P. et al. (2009), Climate policy integration coherence and governance, Partnership for European Environmental Research (PEER) Report 2, PEER, Helsinki. Available online at: http://www.peer.eu/fileadmin/user_upload/publications/PEER_Report2.pdf. 
Midgley, G., Marais, S., Barnett, M. and Wagsaether, K. (2012), "Biodiversity, Climate Change and Sustainable Development - Harnessing Synergies and Celebrating Successes, Final Technical Report” South Africa National Biodiversity Institute, Conservation South Africa and Indigo, January 2012. Available online at:

https://unfccc.int/files/secretariat/momentum_for_change/application/pdf/biodiversity_climate_chan ge sustainable development technical report.pdf.

Naidoo et al. (2012), CTI PFAN Background Paper on Adaptation: An introduction to adaptation in view of developing a private financing approach for adaptation related projects using the CTI PFAN model. Available online at: http://cti-pfan.net/upload/event/file/CTIPFAN_AdaptationPaper.pdf.

OECD (2016), “Creditor Reporting System: Aid activities”, OECD International Development Statistics (database). Available online at: http://dx.doi.org/10.1787/dev-cred-data-en.

OECD (2015a), The Economic Consequences of Climate Change, OECD Publishing, Paris. Available online at: http://dx.doi.org/10.1787/9789264235410-en.

OECD (2015b), Toolkit to Enhance Access to Adaptation Finance: For developing countries that are vulnerable to adverse effects of climate change, including LIDCs, SIDS and African states, Report to the G20 Climate Finance Study Group prepared by the OECD in collaboration with the GEF, Paris: OECD. Available online at: http://www.oecd.org/g20/meetings/istanbul/Toolkit-to-Enhance-Accessto-Adaptation-Finance.pdf.

OECD (2014), Climate Resilience in Development Planning: Experiences in Colombia and Ethiopia, OECD Publishing, Paris. Available online at: https://www.oecd.org/env/climate-resilience-indevelopment-planning-9789264209503-en.htm.

OECD (2013a), From good idea to good practice - options to make resilience work, OECD Publishing, Paris. Available online at: https://www.oecd.org/dac/Experts\%20Group\%20working\%20paper\%20\%200ptions.pdf.

OECD (2013b), Putting Green Growth at the Heart of Development, OECD Publishing, Paris. Available online at: http://www.oecd.org/dac/environment-development/putting-green-growth-at-the-heart-ofdevelopment-9789264181144-en.htm.

OECD (2011), Handbook on the OECD-DAC Rio Markers, OECD Publishing, Paris. Available online at: https://www.oecd.org/dac/stats/48785310.pdf.

OECD (2009), Integrating Climate Change Adaptation into Development Co-operation, OECD Publishing, Paris. Available online at: http://www.oecd.org/dac/environmentdevelopment/integrating-climate-change-adaptation-into-development-co-operation-policyguidance-9789264054950-en.htm.

OECD (2008), Economic Aspects of Adaptation to Climate Change. Costs, Benefits and Policy Instruments, OECD Publishing, Paris. Available online at: http://www.oecd.org/env/cc/economicaspectsofadaptationtoclimatechangecostsbenefitsandpolicyinst ruments.htm.

OECD (2007a), Promoting Pro-Poor Growth: Policy Guidance for Donors, OECD Publishing, Paris. Available online at: https://www.oecd.org/dac/povertyreduction/43773640.pdf. 
OECD (2007b), Reporting Directives for the Creditor Reporting System, Addendum on the Climate Change Adaptation Marker (DCD/DAC(2007)39/FINAL/ADD3), OECD, Paris.

OECD (2005), Bridge over Troubled Waters: Linking Climate Change and Development, OECD Publishing, Paris. Available online at: http://www.oecd.org/env/cc/36174361.pdf.

OECD-CPI (2015), Climate Finance in 2013-14 and the USD 100 billion goal: A report by the OECD in collaboration with the Climate Policy Initiative, OECD Publishing, Paris. Available online at: http://www.oecd.org/env/cc/Climate-Finance-in-2013-14-and-the-USD-billion-goal.pdf.

Pauw, P. and A. Pegels (2013), Private sector engagement in climate change adaptation in least developed countries: an exploration, Climate and Development 5(4): 257-267. Available online at: http://www.tandfonline.com/doi/abs/10.1080/17565529.2013.826130.

Peters, G. P. et al. (2012), “The challenge to keep global warming below $2^{\circ} \mathrm{C}$ ”, Nature Climate Change 3: 4-6. Available online at: http://www.nature.com/nclimate/journal/v3/n1/full/nclimate1783.html.

Reid, H. (2015), "Ecosystem- and community-based adaptation: learning from community-based natural resource management”, Climate and Development 8(1): 4-9. Available online at: http://dx.doi.org/10.1080/17565529.2015.1034233.

Rockström, J. et al., (2009), "Planetary Boundaries: Exploring the Safe Operating Space for Humanity”, Ecology and Society 14(2): 32. Available online at: http://ced.agro.uba.ar/granchaco/sites/default/files/pdf/sem6/Rockstorm\%20et\%20al\%202009.pdf.

Smallridge, D. et al., (2012), “The Role of National Development Banks in Intermediating International Climate Finance to Scale Up Private Sector Investments”, Inter-American Development Bank Institutions for Development (IFD) Discussion Paper No. IDB-DP-249, Washington D.C.: InterAmerican Development Bank. Available online at: http://idbdocs.iadb.org/wsdocs/getdocument.aspx?docnum=37292040.

Smit, B. and J. Wandel (2006), “Adaptation, adaptive capacity and vulnerability”, Global Environmental Change 16(3): 282-292. Available online at: http://www.sciencedirect.com/science/article/pii/S0959378006000410.

Standard and Poor's (2015), "Climate Change is a Global Mega-Trend for Sovereign Risk", Available online at:

https://www.globalcreditportal.com/ratingsdirect/renderArticle.do?articleId=1318252\&SctArtId=23 6925\&from=CM\&nsl_code=LIME\&sourceObjectId=8606813\&sourceRevId=1\&fee_ind=N\&exp_d ate $=20240514-20: 34: 43$.

Tanner, T. and L. Horn-Phathanothai (2013), Climate Change and Development, Routledge, Abingdon.

Tanner, T. and T. Mitchell (2008), "Entrenchment or Enhancement: Could Climate Change Adaptation Help Reduce Chronic Poverty?”, IDS Bulletin 39(4): 6-15. Available online at: http://www.ids.ac.uk/publication/poverty-in-a-changing-climate.

The Economics of Ecosystems and Biodiversity (TEEB) (2009), The Economics of Ecosystems and Biodiversity for National and International Policy Makers. Available online at: http://www.teebweb.org/. 
Terpstra, P. et al. (2013), “The plumbing of adaptation finance: accountability, transparency and accessibility at the local level”, WRI Working Paper, WRI, Washington DC. Available online at: http://www.wri.org/publication/the-plumbing-of-adaptation-finance.

United Nations (2015), Transforming our World: The 2030 Agenda for Sustainable Development, A/RES/70/1, United Nations, New York. Available online at: https://sustainabledevelopment.un.org/post2015/transformingourworld.

United Nations (2014), World Urbanisation Prospects - The 2014 Revision, Department of Economic and Social Affairs, United Nations, New York. Available online at: https://esa.un.org/unpd/wup/Publications/Files/WUP2014-Highlights.pdf.

United Nations Development Programme (UNDP) (2007), Human Development Report 2007/2008 Fighting Climate Change: Human Solidarity in a Divided World, United Nations Development Programme, New York. Available online at: http://hdr.undp.org/en/content/human-developmentreport-20078.

United Nations Environment Programme (UNEP) (2011), Human Development Report 2011 Sustainability and Equity: A Better Future for All, Palgrave Macmillan, New York. Available online at: http://hdr.undp.org/sites/default/files/reports/271/hdr_2011 en complete.pdf.

United Nations Framework Convention on Climate Change (UNFCCC) (2015), Adoption of the Paris Agreement, UNFCCC/CP/2015/L.9/Rev.1, UNFCCC, Bonn. Available online at: https://unfccc.int/resource/docs/2015/cop21/eng/109r01.pdf.

UNFCCC (2013), The State of Adaptation under the United Nations Framework Convention on Climate Change, United Nations Framework Convention on Climate Change Secretariat, Bonn. Available online at:

https://unfccc.int/files/adaptation/cancun_adaptation_framework/adaptation_committee/application/ pdf/ac_2013_report_low_res.pdf.

UNFCCC (2002), Guidelines for the preparation of national adaptation programmes of action, UNFCCC/2001/13Add.3, Decision 28/CP.7, UNFCCC, Bonn. Available online at: http://unfccc.int/files/adaptation/methodologies_for/vulnerability_and_adaptation/application/pdf/gu idelines for the preparation of napas.pdf.

United Nations Framework Convention on Climate Change Least Developed Countries' Experg Group (UNFCCC/LEG) (2012), Technical Guidelines for the National Adaptation Plan Process, UNFCCC Secretariat, Bonn. Available online at:

https://unfccc.int/files/adaptation/cancun_adaptation_framework/application/pdf/naptechguidelines_ eng_high_res.pdf.

UNFCCC/ LEG (2011), Identification and implementation of medium- and long-term adaptation activities in least developed countries. Technical Paper, UNFCCC Secretariat, Bonn. Available online at: http://unfccc.int/resource/docs/2011/tp/07.pdf.

Urwin, K. and A. Jordan (2008), "Does public policy support or undermine climate change adaptation? Exploring policy interplay across different scales of government”, Global Environmental Change 18: 180-191. Available online at: https://www.humphreyfellowship.org/system/files/Does\%20public\%20policy\%20support\%20or\%20 undermine\%20climate\%20change\%20adaptation.pdf. 
World Bank (2015), Agriculture, value added (\% of GDP), dataset. Available online at: http://data.worldbank.org/indicator/NV.AGR.TOTL.ZS, accessed 4 June 2015.

World Bank (2012), Turn down the heat: Why a $4^{\circ} \mathrm{C}$ warmer world must be avoided, World Bank, Washington D.C. Available online at:

http://documents.worldbank.org/curated/en/2012/11/17097815/turn-down-heat-4\%C2\%B0cwarmer-world-must-avoided.

World Bank (2010), World Development Report 2010: Development and Climate Change, World Bank, Washington D.C. Available online at:

http://siteresources.worldbank.org/INTWDR2010/Resources/5287678-1226014527953/WDR10Full-Text.pdf.

World Bank (2006), Investment Framework for Clean Energy and Development, World Bank, Washington D.C. Available online at: http://siteresources.worldbank.org/SOUTHASIAEXT/Resources/223546$1171488994713 / 3455847-$ 1189621792121/AnInvestmentFrameworkforCleanEnergyandDevelopment.pdf.

World Bank (2004), Sustaining Forests: A Development Strategy, World Bank, Washington D.C. Available online at: http://siteresources.worldbank.org/INTFORESTS/Resources/SustainingForests.pdf.

World Resources Institute (WRI) (2015), With New Climate Plans, Adaptation is No Longer an Overlooked Issue, World Resources Institute Blog. Available online at: http://www.wri.org/blog/2015/11/new-climate-plans-adaptation-no-longer-overlooked-issue

WRI (2011), World Resources 2010-2011 - Decision Making in a Changing Climate: Adaptation Challenges and Choices, WRI, Washington D.C. Available online at: http://pdf.wri.org/world_resources_report_2010-2011.pdf.

\section{National Development Plans}

Government of the People’s Republic of Bangladesh, Ministry of Planning, Planning Commission (2011), Sixth Five Year Plan FY 2011-FY 2015 - Accelerating Growth and Reducing Poverty, Part 1 Strategic Directions and Policy Framework, Planning Commission, Government of the People’s Republic of Bangladesh, Dhaka.

Government of the People’s Republic of Bangladesh, Ministry of Planning, Planning Commission (2011), Sixth Five Year Plan FY 2011-FY 2015 - Accelerating Growth and Reducing Poverty, Part 2 Sectoral Strategies, Programmes and Policies, Planning Commission, Government of the People's Republic of Bangladesh, Dhaka.

Bolivia, Ministerio de Planificación del Desarrollo (2006) Plan Nacional de Desarrollo, Ministerio de Planificación del Desarrollo, La Paz.

Royal Government of Cambodia (2014), National Strategic Development Plan 2014-2018, Royal Government of Cambodia, Phnom Penh.

Gobierno de Costa Rica, Ministerio de Planificación Nacional y Política Económica (2014), Plan Nacional de Desarrollo 2015-2018 “Alberto Cañas Escalante”, Ministerio de Planificación Nacional y Política Económica, San Jose. 
Federal Democratic Republic of Ethiopia Ministry of Finance and Economic Development (2010), Growth and Transformation Plan 2010/11-2014/15, Volume I: Main Text, Ministry of Finance and Economic Development, Federal Democratic Republic of Ethiopia, Addis Ababa.

Federal Democratic Republic of Ethiopia Ministry of Finance and Economic Development (2010), Growth and Transformation Plan 2010/11-2014/15, Volume II: Policy Matrix, Ministry of Finance and Economic Development, Federal Democratic Republic of Ethiopia, Addis Ababa.

Government of India Planning Commission (2013), Twelfth Five Year Plan (2012-2017) - Faster, More Inclusive and Sustainable Growth, Volume I, Planning Commission, Government of India, New Delhi.

Government of India Planning Commission (2013), Twelfth Five Year Plan (2012-2017) - Faster, More Inclusive and Sustainable Growth, Volume II - Economic Sectors, Planning Commission, Government of India, New Delhi.

Government of India Planning Commission (2013), Twelfth Five Year Plan (2012-2017) - Faster, More Inclusive and Sustainable Growth, Volume III - Social Sectors, Planning Commission, Government of India, New Delhi.

Indonesia National Ministry of National Development Planning (2010), Second National Medium-term Development Plan (RPJMN) 2010-2014, Book I National Priorities, Ministry of National Development Planning/National Development Planning Agency, Jakarta.

Republic of Kenya Ministry of Devolution and Planning (2013), Second Medium Term Plan, 2013-2017, Republic of Kenya, Nairobi.

Centro Nacional de Planeamiento Estratégico de Perú (2011), Plan Bicentenario - El Perú hacia el 2021, Centro Nacional de Planeamiento Estratégico de Perú, Lima.

Philippine National Economic and Development Authority (2011), Philippine Development Plan 20112016, National Economic and Development Authority, Pasig City.

Government of the Solomon Islands Ministry of Development Planning and Aid Coordination (2011), National Development Strategy 2011 to 2020, Ministry of Development Planning and Aid Coordination, Honiara.

United Republic of Tanzania, President's Office, Planning Commission (2011), The Tanzania Five Year Development Plan 2011/2012-2015/2016 - Unleashing Tanzania's Latent Growth Potentials, United Republic of Tanzania, President’s Office, Planning Commission, Dodoma.

République Tunisienne - Ministère du Développement Régional et de la Planification (2012), Stratégie de Développement de la Tunisie Nouvelle, République Tunisienne, Tunis.

Republic of Tunisia (2010), Economic and social Development in Tunisia 2010-2014 - Towards an innovation and creation based growth, Republic of Tunisia, Tunis.

Socialist Republic of Viet Nam (2011), Viet Nam's Socio-economic Development Strategy for the Period of 2011-2020 (unofficial translation by www.economica.vn), Socialist Republic of Viet Nam, Hanoi.

Republic of Zambia (2011), Sixth National Development Plan 2011-2015 - "Sustained economic growth and poverty reduction”, Republic of Zambia, Lusaka. 


\section{Climate Change Plans}

Government of the People's Republic of Bangladesh, Ministry of Environment and Forests (2009), Bangladesh Climate Change Strategy and Action Plan 2009, Ministry of Environment and Forests, Government of the People’s Republic of Bangladesh, Dhaka.

Bolivia, Viceministerio de Medio Ambiente, Biodiversidad y Cambios Climáticos (2009), Estrategia Nacional Bosque y Cambio Climático, Viceministerio de Medio Ambiente, La Paz.

Royal Government of Cambodia (2013), Cambodia Climate Change Strategic Plan, Royal Government of Cambodia, Phnom Penh.

Costa Rica, Ministerio de Ambiente, Energía y Telecomunicaciones (2009), Estrategia Nacional de Cambio Climático, Editor Calderón y Alvarado S.A., San José.

Costa Rica, Dirección Cambio Climático (2012), Plan de Acción Estrategia Nacional de Cambio Climático, Dirección Cambio Climático, San José.

Federal Democratic Republic of Ethiopia (2011), Ethiopia's Climate-Resilient Green Economy, Green economy strategy, Federal Democratic Republic of Ethiopia, Addis Ababa.

Federal Democratic Republic of Ethiopia (2011), Ethiopia's Vision for a Climate Resilient Green Economy, Republic of Ethiopia, Addis Ababa.

Government of India, Prime Minister's Council on Climate Change (2008), National Action Plan on Climate Change, Government of India, New Delhi.

Republic of Indonesia (2007), National Action Plan Addressing Climate Change, State Ministry of Environment, Republic of Indonesia, Jakarta.

Republic of Kenya (2013), National Climate Change Action Plan 2013-2017, Ministry of Environment and Mineral Resources, Republic of Kenya, Nairobi.

Ministerio del Ambiente de Perú (2014), Estrategia Nacional ante el Cambio Climático, Ministerio del Ambiente de Perú, Lima.

Ministerio del Ambiente de Perú (2014), Plan de Acción de Adaptación y Mitigación frente al Cambio Climático, Ministerio del Ambiente de Perú, Lima.

Republic of the Philippines Climate Change Commission (2011), National Climate Change Action Plan 2011-2028, Republic of the Philippines Climate Change Commission, Manila.

Solomon Islands Government Ministry of Environment, Climate Change, Disaster Management and Meteorology (2012), National Climate Change Policy 2012-2017, Solomon Islands Government Ministry of Environment, Climate Change, Disaster Management and Meteorology, Honiara.

United Republic of Tanzania Vice President's Office, Division of Environment (2012), National Climate Change Strategy, United Republic of Tanzania Vice President’s Office, Dodoma.

République Tunisienne, Ministère de l’Environnement, Direction Générale du Développement Durable (2011), Stratégie Nationale du Développement Durable, République Tunisienne, Tunis. 
République Tunisienne, Ministère de l’Environnement, et GIZ (Coopération Allemande au Développement) (2012), Stratégie Nationale sur le Changement Climatique - Rapport de la stratégie, Tunis.

Socialist Republic of Viet Nam (2011), National strategy on climate change, Period 2011-2020, Socialist Republic of Viet Nam, Hanoi.

Government of the Republic of Zambia, Ministry of Tourism, Environment and Natural Resources (2010), National Climate Change Response Strategy, Republic of Zambia, Lusaka. 
Annex 1. The extent to which climate change adaptation is integrated into national development plans in select countries

\begin{tabular}{|c|c|c|c|c|}
\hline \multirow{2}{*}{$\begin{array}{c}\text { Country } \\
\text { (Year of Plan) }\end{array}$} & \multirow{2}{*}{ Integration of adaptation into National Development Plan (NDP) } & \multirow{2}{*}{$\begin{array}{l}\text { Share of bilateral } \\
\text { ODA targeting } \\
\text { adaptation in } \\
2011-13\end{array}$} & \multicolumn{2}{|c|}{$\begin{array}{l}\text { Bilateral ODA commitments targeting } \\
\text { adaptation, USD million, annual average } \\
\text { 2011-2013 }\end{array}$} \\
\hline & & & Total & $\begin{array}{c}\text { (\% Principal, \% } \\
\text { Significant) }\end{array}$ \\
\hline $\begin{array}{l}\text { Bangladesh } \\
\text { (2011) }\end{array}$ & $\begin{array}{l}\text { Adaptation is recognised as central to Bangladesh's development process, is highlighted as a top priority, } \\
\text { and is integrated into a wide range of sectors. These are: agriculture/food security, environmental resource } \\
\text { management, poverty reduction/social protection, health, water, disaster management, infrastructure, } \\
\text { research and knowledge management, capacity building and institutional strengthening }\end{array}$ & $16 \%$ & 296 & $(66 \%, 34 \%)$ \\
\hline $\begin{array}{c}\text { Cambodia } \\
\text { (2014) }\end{array}$ & $\begin{array}{l}\text { Adaptation is well integrated into entire plan. Explicitly highlighted in the following sectors: agriculture, } \\
\text { infrastructure (especially for rural development and roads), water (especially irrigation and dams), energy, } \\
\text { health, disaster management, forestry, fisheries and environmental protection. }\end{array}$ & $18 \%$ & 119 & $(55 \%, 45 \%)$ \\
\hline $\begin{array}{l}\text { Costa Rica } \\
\text { (2015) }\end{array}$ & $\begin{array}{l}\text { Adaptation is clearly a priority in the NDP. Adaptation identified as one of } 10 \text { core cross-cutting issues } \\
\text { essential for the success of the NDP. Adaptation is well integrated into the agriculture sector and is one of } \\
\text { three core objectives of the environment sector. The adaptation and disaster risk reduction programme of } \\
\text { action focuses on vulnerable sectors - agriculture, infrastructure, housing, coastal and fishing zones, } \\
\text { biodiversity, water resources, and energy. }\end{array}$ & $27 \%$ & 16 & $(2 \%, 98 \%)$ \\
\hline $\begin{array}{c}\text { Philippines } \\
\text { (2011) }\end{array}$ & $\begin{array}{l}\text { Adaptation is well integrated into the entire plan. It is explicitly linked to inclusive growth, and integrated into } \\
\text { the following sectors: industry and services, mining, small and medium enterprise development, agriculture } \\
\text { and fisheries, infrastructure, energy, social development, peace and security, and environmental/natural } \\
\text { resource management. }\end{array}$ & $13 \%$ & 209 & $(25 \%, 75 \%)$ \\
\hline $\begin{array}{c}\text { Zambia } \\
\text { (2011) }\end{array}$ & $\begin{array}{l}\text { Adaptation is well integrated into the entire plan. Explicitly highlighted in the following sectors: natural } \\
\text { resource management, disaster risk management, infrastructure, health, water, agriculture/forests/fisheries, } \\
\text { mining, tourism, science/technology/innovation, education and skills. Also focuses on integrating adaptation } \\
\text { into local government and district development plans. }\end{array}$ & $9 \%$ & 73 & $(24 \%, 76 \%)$ \\
\hline $\begin{array}{l}\text { Bolivia } \\
\text { (2006) }\end{array}$ & $\begin{array}{l}\text { Adaptation programme is detailed but predominantly restricted to the "Natural Resources" section. The } \\
\text { description in this section does however link adaptation with a broad range of sectors: disaster prevention in } \\
\text { agriculture and in rural and urban infrastructure; water and energy management for vulnerable subsistence } \\
\text { communities; education. }\end{array}$ & $26 \%$ & 103 & $(21 \%, 79 \%)$ \\
\hline $\begin{array}{l}\text { India } \\
\text { (2012) }\end{array}$ & $\begin{array}{l}\text { Adaptation is partly integrated into the NDP. In strategic directives, adaptation is discussed in the chapters } \\
\text { on sustainable development, water, environment forestry and wildlife. Within the latter, there is a whole } \\
\text { section on adaptation, which links adaptation to agriculture, forests and ecosystems, water, coasts, health, } \\
\text { infrastructure, and industry. However in the volume of the NDP on economic sectors, adaptation is well } \\
\text { integrated into agriculture but not into other sectors. }\end{array}$ & $13 \%$ & 532 & $(8 \%, 92 \%)$ \\
\hline $\begin{array}{l}\text { Indonesia } \\
\text { (2010) }\end{array}$ & $\begin{array}{l}\text { Adaptation is partly integrated into the NDP. The introductory section notes the importance of adaptation } \\
\text { policies for economic development. Adaptation is mentioned in some detail in the context of food } \\
\text { security/agriculture, environmental management, and technological innovation. }\end{array}$ & $6 \%$ & 119 & $(50 \%, 50 \%)$ \\
\hline $\begin{array}{l}\text { Kenya } \\
\text { (2013) }\end{array}$ & $\begin{array}{l}\text { Adaptation is partly integrated into the NDP. Climate change is recognised as one of the key issues and the } \\
\text { remaining or emerging challenges, both in the introduction and in a variety of sectors such as water, natural } \\
\text { disasters (floods and droughts), energy and environment. The NDP is more focused on the challenges than } \\
\text { the solutions. Solutions proposed for agriculture, forests and drought resilience. }\end{array}$ & $8 \%$ & 172 & $(38 \%, 62 \%)$ \\
\hline
\end{tabular}




\begin{tabular}{|c|c|c|c|c|}
\hline \multirow{2}{*}{$\begin{array}{l}\text { Country } \\
\text { (Year of Plan) }\end{array}$} & \multirow{2}{*}{ Integration of adaptation into National Development Plan (NDP) } & \multirow{2}{*}{$\begin{array}{l}\text { Share of bilateral } \\
\text { ODA targeting } \\
\text { adaptation in } \\
2011-13\end{array}$} & \multicolumn{2}{|c|}{$\begin{array}{l}\text { Bilateral ODA commitments targeting } \\
\text { adaptation, USD million, annual average } \\
2011-2013\end{array}$} \\
\hline & & & Total & $\begin{array}{l}\text { (\% Principal, \% } \\
\text { Significant) }\end{array}$ \\
\hline $\begin{array}{c}\text { Peru } \\
\text { (2011) }\end{array}$ & $\begin{array}{l}\text { The adaptation programme is detailed, but is only treated in the sections on environmental management and } \\
\text { agriculture. Adaptation is one of the five environmental priorities. The plan emphasises integration of } \\
\text { adaptation considerations into policies at all three levels of governance (national, regional, local). The } \\
\text { adaptation programme in the "environmental management" chapter links adaptation to watershed } \\
\text { management, biodiversity and ecosystems, and infrastructure. }\end{array}$ & $23 \%$ & 139 & $(16 \%, 84 \%)$ \\
\hline $\begin{array}{l}\text { Ethiopia } \\
\text { (2010) }\end{array}$ & $\begin{array}{l}\text { Environment and climate change (including adaptation) is identified as a cross-cutting issue, but adaptation } \\
\text { measures are listed only in the section on environment and climate change. Here, links are made to forests, } \\
\text { wetlands, infrastructure (e.g. dams, roads) and biological resource conservation. }\end{array}$ & $10 \%$ & 194 & $(27 \%, 73 \%)$ \\
\hline $\begin{array}{l}\text { Solomon Islands } \\
\text { (2011) }\end{array}$ & $\begin{array}{l}\text { Adaptation is rarely mentioned in the plan, and climate change issues are treated only in the section on } \\
\text { "Environment and Climate Change". This links climate change to a few sectors: food security, tourism, } \\
\text { disaster risk management and response. Sustainable environmental management is discussed but not } \\
\text { linked to adaptation. }\end{array}$ & $12 \%$ & 33 & $(9 \%, 91 \%)$ \\
\hline $\begin{array}{c}\text { Tanzania } \\
\text { (2011) }\end{array}$ & $\begin{array}{l}\text { Adaptation is recognised as important for sustainable economic growth, but discussed predominantly in the } \\
\text { section on environment and climate change, focusing on institutional structures and finance for climate } \\
\text { change. Adaptation is also linked briefly to water management, agriculture and tourism. }\end{array}$ & $11 \%$ & 185 & $(6 \%, 94 \%)$ \\
\hline $\begin{array}{l}\text { Tunisia } \\
(2010)\end{array}$ & $\begin{array}{l}\text { Adaptation is not mentioned in the NDP. Climate change appears only once, in the section on the } \\
\text { environment. Adaptation is treated in a separate national sustainable development strategy. }\end{array}$ & $12 \%$ & 156 & $(25 \%, 75 \%)$ \\
\hline $\begin{array}{l}\text { Viet Nam } \\
\text { (2011) }\end{array}$ & $\begin{array}{l}\text { Adaptation and responses to climate change are only treated very briefly in the plan, in the section on } \\
\text { environmental management and on rural and urban development. }\end{array}$ & $17 \%$ & 583 & $(33 \%, 67 \%)$ \\
\hline
\end{tabular}

Source: see bibliography for list of National Development Plans reviewed.

Notes: (1) The classifications are applied as follows: Green: Adaptation is widely integrated throughout the document, in a wide variety of sectors, and is mentioned frequently and in detail. Yellow: Adaptation is discussed in some detail, mainly in the section on environment and climate change, but is also linked to some other sectors. Red: climate change adaptation is not mentioned or is mentioned very briefly in the document. It is only mentioned within the context of environment and climate change, and referred to in few if any other sectors. (2) These classifications are based solely upon each country's national development plan, as this review focused on the question of how well adaptation is integrated throughout a country's national development plan. Many countries also have sustainable development or green growth plans, and all countries also have climate change plans, in which adaptation actions are discussed in more detail. Many countries also have established governance structures and finance plans/mechanisms for adaptation, which may not be reflected in the national development plan. 
Annex 2. Linkages between adaptation and other environment and development issues in national development and climate change plans






\begin{tabular}{|c|c|c|c|c|c|}
\hline Country & Plan & Biodiversity and ecosystems & Livelihoods and poverty reduction & Rural development & Urban development \\
\hline \multirow[t]{2}{*}{ Costa Rica } & $\begin{array}{l}\text { National } \\
\text { Development } \\
\text { Plan (2015) }\end{array}$ & $\begin{array}{l}\text { The plan has a specific programme on } \\
\text { ecosystem-based adaptation, focusing on } \\
\text { watersheds, landscapes, and biological } \\
\text { corridors. }\end{array}$ & $\begin{array}{l}\text { Highlights need for full engagement and } \\
\text { participation of local communities in } \\
\text { adaptation measures, e.g. community } \\
\text { forestry, soil conservation. Adaptation } \\
\text { well integrated into the agriculture } \\
\text { sector, which is important for } \\
\text { livelihoods, although the word } \\
\text { "livelihoods" is not mentioned. }\end{array}$ & $\begin{array}{l}\text { Notes need to reduce climate risk in } \\
\text { rural areas - including integrating } \\
\text { climate vulnerability considerations } \\
\text { into housing and public infrastructure } \\
\text { in risk zones. }\end{array}$ & $\begin{array}{l}\text { Notes the need to reduce climate risk } \\
\text { in urban areas - including integrating } \\
\text { climate vulnerability considerations } \\
\text { into housing and public infrastructure } \\
\text { in risk zones. }\end{array}$ \\
\hline & $\begin{array}{l}\text { Climate } \\
\text { Change Plan } \\
\text { (2012) }\end{array}$ & $\begin{array}{l}\text { Adaptation actions in coastal areas focus on } \\
\text { mangrove planting and protecting coral } \\
\text { reefs. }\end{array}$ & $\begin{array}{l}\text { Notes that forests are important for } \\
\text { local vulnerable populations, and } \\
\text { reforestation and forest protection are } \\
\text { raised as a climate change measure } \\
\text { (though not specifically for adaptation). }\end{array}$ & $\begin{array}{l}\text { Adaptation measures linked to health } \\
\text { are particularly emphasised for rural } \\
\text { areas. Reforestation highlighted as } \\
\text { particularly benefiting rural areas. }\end{array}$ & $\begin{array}{l}\text { Infrastructure one of the key areas } \\
\text { targeted by adaptation measures. }\end{array}$ \\
\hline \multirow[b]{2}{*}{ Ethiopia } & $\begin{array}{l}\text { National } \\
\text { Development } \\
\text { Plan (2010) }\end{array}$ & $\begin{array}{l}\text { A number of ecosystem-based adaptation } \\
\text { approaches are laid out under natural } \\
\text { resource conservation, such as land } \\
\text { rehabilitation, reforestation, but they are not } \\
\text { explicitly linked to adaptation. }\end{array}$ & $\begin{array}{l}\text { Dams, road and other infrastructure } \\
\text { linked to poverty reduction, and it is } \\
\text { highlighted that these need to be made } \\
\text { climate resilient. }\end{array}$ & $\begin{array}{l}\text { Dams, roads and other infrastructure } \\
\text { facilities to be built to be climate } \\
\text { resilient (not specified if rural or } \\
\text { urban). Natural resource } \\
\text { conservation and disaster mitigation } \\
\text { and management appear in the } \\
\text { policy matrix for "Agriculture and } \\
\text { Rural Development". }\end{array}$ & $\begin{array}{l}\text { Dams, roads and other infrastructure } \\
\text { facilities to be built to be climate } \\
\text { resilient (unclear if rural or urban). }\end{array}$ \\
\hline & $\begin{array}{l}\text { Climate } \\
\text { Change Plan } \\
(2011)\end{array}$ & $\begin{array}{l}\text { A pillar is re-establishing forests for their } \\
\text { economic and ecosystem services. }\end{array}$ & $\begin{array}{l}\text { Improving crop and livestock production } \\
\text { for higher food security is one pillar of } \\
\text { the plan. Agriculture and the use of } \\
\text { natural resources (water, land, forests, } \\
\text { fisheries, biodiversity) are linked to } \\
\text { livelihoods and wellbeing, and noted as } \\
\text { vulnerable to climate change, thereby } \\
\text { necessitating adaptation action (e.g. the } \\
\text { diversification of livelihoods). }\end{array}$ & $\begin{array}{l}\text { Climate change actions (doesn't } \\
\text { specify mitigation or adaptation or } \\
\text { both) recognised to promote rural } \\
\text { economic development by increasing } \\
\text { soil fertility and food security. }\end{array}$ & $\begin{array}{l}\text { Preventing biomass and soil nutrient } \\
\text { accumulation in urban areas listed as } \\
\text { an adaptation measure. Establishing } \\
\text { building and construction codes for } \\
\text { increased climate resilience listed as } \\
\text { another measure. }\end{array}$ \\
\hline \multirow[t]{2}{*}{ India } & $\begin{array}{l}\text { National } \\
\text { Development } \\
\text { Plan (2012) }\end{array}$ & $\begin{array}{l}\text { Forests recognised as contributing to } \\
\text { climate change adaptation. Reforestation } \\
\text { and afforestation programmes and } \\
\text { sustainable forest management are listed as } \\
\text { adaptation measures. }\end{array}$ & $\begin{array}{l}\text { Livelihoods linked to forests, which are } \\
\text { at risk to impact of climate change. }\end{array}$ & $\begin{array}{l}\text { Infrastructure needs to take climate } \\
\text { change impacts into account, } \\
\text { particularly near the coast (not clear } \\
\text { whether rural or urban). Sustainable } \\
\text { Agriculture mission is to make } \\
\text { agriculture more resilient to climate } \\
\text { change. Link with rural development } \\
\text { not explicitly mentioned. }\end{array}$ & $\begin{array}{l}\text { Infrastructure needs to take climate } \\
\text { change impacts into account, } \\
\text { particularly near the coast (not clear } \\
\text { whether rural or urban). Sustainable } \\
\text { Habitat mission focuses on green } \\
\text { cities, however the word "adaptation" } \\
\text { is not mentioned. }\end{array}$ \\
\hline & $\begin{array}{l}\text { Climate } \\
\text { Change Plan } \\
\text { (2008) }\end{array}$ & $\begin{array}{l}\text { Conservation of wetlands, afforestation } \\
\text { programme, planting coastal forests and } \\
\text { mangroves mentioned in context of } \\
\text { adaptation. }\end{array}$ & $\begin{array}{l}\text { Promote sustainable tourism to help } \\
\text { locals to gain better livelihoods while } \\
\text { protecting ecosystems. Coastal } \\
\text { resources and agriculture directly linked } \\
\text { to livelihoods, have adaptation plans for } \\
\text { each of these areas. }\end{array}$ & $\begin{array}{l}\text { Has a national mission for } \\
\text { Sustainable Agriculture, to ensure } \\
\text { that agriculture is well adapted to } \\
\text { climate change, as agriculture is } \\
\text { essential India's } \\
\text { economy/livelihoods - bo but rural } \\
\text { development not explicitly mentioned. }\end{array}$ & $\begin{array}{l}\text { Integrating adaptation } \\
\text { concerns/vulnerability to natural } \\
\text { disasters into infrastructure design. } \\
\text { Enforcing building codes and better } \\
\text { urban planning for adaptation. }\end{array}$ \\
\hline Indonesia & $\begin{array}{l}\text { National } \\
\text { Development } \\
\text { Plan (2010) }\end{array}$ & $\begin{array}{l}\text { Rehabilitating forests and land, sustainable } \\
\text { watershed management, mentioned in } \\
\text { context of climate policy. Halting } \\
\text { environmental degradation in river basins to } \\
\text { reduce natural disaster vulnerability. }\end{array}$ & $\begin{array}{l}\text { Adaptation is linked to economic } \\
\text { growth, welfare and food security - } \\
\text { thereby to livelihoods }\end{array}$ & & $\begin{array}{l}\text { Discusses flood control infrastructure, } \\
\text { but not directly linked to adaptation. }\end{array}$ \\
\hline
\end{tabular}




\begin{tabular}{|c|c|c|c|c|c|}
\hline Country & Plan & Biodiversity and ecosystems & Livelihoods and poverty reduction & Rural development & Urban development \\
\hline & $\begin{array}{l}\text { Climate } \\
\text { Change Plan } \\
\quad(2007)\end{array}$ & $\begin{array}{l}\text { Integrated coastal management through } \\
\text { mangrove planting, coral reef } \\
\text { transplantation. Land rehabilitation and } \\
\text { reforestation and afforestation as an } \\
\text { adaptation and mitigation measure, } \\
\text { particularly to help protect river watersheds. } \\
\text { Mention of agricultural development that } \\
\text { takes ecosystems into consideration so that } \\
\text { it is sustainable (as part of adaptation plan). }\end{array}$ & $\begin{array}{l}\text { Impact of climate change directly linked } \\
\text { to livelihoods e.g. those in coastal } \\
\text { villages. Developing ecotourism in } \\
\text { coastal area to prevent mangroves } \\
\text { being used as a source of energy (i.e. } \\
\text { finding alternative livelihoods). Coastal } \\
\text { replanting focusing on community } \\
\text { empowerment. Adaptation in agriculture } \\
\text { sector focused on food security and } \\
\text { farmer welfare. Getting fishermen and } \\
\text { other coastal workers to plant and take } \\
\text { care of the mangroves }\end{array}$ & $\begin{array}{l}\text { Rehabilitation of sustainable peat } \\
\text { land, river watershed programmes, } \\
\text { conservation and cultivation areas in } \\
\text { the Heart of Borneo, and improving } \\
\text { land policy (particularly concerning } \\
\text { land titles) - linked to adaptation, but } \\
\text { doesn't explicitly use the word "rural } \\
\text { development". Detailed adaptation } \\
\text { plan for agriculture sector. }\end{array}$ & $\begin{array}{l}\text { Urban centres recognised as at risk } \\
\text { to impacts of climate change. Focus } \\
\text { on mainstreaming adaptation into } \\
\text { infrastructure planning and design } \\
\text { including water infrastructure } \\
\text { (drinking, water, irrigation, industry } \\
\text { flood control, drainage), road } \\
\text { construction, community housing. }\end{array}$ \\
\hline \multirow[b]{2}{*}{ Kenya } & $\begin{array}{l}\text { National } \\
\text { Development } \\
\text { Plan (2013) }\end{array}$ & $\begin{array}{l}\text { Forests recognised as providing adaptation } \\
\text { to climate change, mangroves recognised } \\
\text { for shoreline stabilisation. }\end{array}$ & $\begin{array}{l}\text { Ecosystem and participatory forest } \\
\text { management plans to support } \\
\text { sustainable forest management. Nature } \\
\text { based enterprises promoted for poverty } \\
\text { alleviation. Not explicitly linked with } \\
\text { adaptation, but the role of forests in } \\
\text { climate change adaptation is } \\
\text { recognised earlier in the section. Later, } \\
\text { adaptation is linked to livelihoods and } \\
\text { drought. }\end{array}$ & $\begin{array}{l}\text { Has one objective to reclaim land for } \\
\text { irrigation, to enhance capacity and } \\
\text { build resilience of communities in } \\
\text { reclaimed areas to respond to climate } \\
\text { change. Another objective to adopt } \\
\text { climate-smart agriculture. Not } \\
\text { explicitly linked to rural development. }\end{array}$ & \\
\hline & $\begin{array}{l}\text { Climate } \\
\text { Change Plan } \\
\quad(2013)\end{array}$ & $\begin{array}{l}\text { Forest cover recognised as being important } \\
\text { for climate resilience (e.g. preventing } \\
\text { flooding and landslides). Coastal zone } \\
\text { management including conserving coastal } \\
\text { ecosystems, listed as an adaptation } \\
\text { measure. Ecosystem-based adaptation } \\
\text { explicitly mentioned, in relation to increasing } \\
\text { forest cover. }\end{array}$ & $\begin{array}{l}\text { Notes that forest conservation can } \\
\text { improve livelihoods. Prioritises } \\
\text { adaptation actions to improve water } \\
\text { management, e.g. linked to agricultural } \\
\text { and livestock production, to reduce the } \\
\text { impact of droughts and floods on } \\
\text { livelihoods. Livelihood diversification is } \\
\text { cited as an adaptation measure. } \\
\text { Supports sustainable livelihoods in } \\
\text { drought-prone areas. Building resilience } \\
\text { in vulnerable tourism areas. }\end{array}$ & $\begin{array}{l}\text { Priority adaptation actions include } \\
\text { increased domestic water supply, } \\
\text { improved sewage systems, } \\
\text { enhanced irrigation to improve } \\
\text { agriculture and livestock production, } \\
\text { flood mitigation schemes and } \\
\text { (although not explicitly linked to rural } \\
\text { development). }\end{array}$ & $\begin{array}{l}\text { Highlights the need to climate-proo } \\
\text { infrastructure, e.g. transpon } \\
\text { infrastructure. Actions will include } \\
\text { improved use of weather and climate } \\
\text { information in infrastructure } \\
\text { development, identifying designs and } \\
\text { materials to enhance resilience } \\
\text { regulations and codes, climate risk } \\
\text { screening. Also prioritise expandec } \\
\text { flood management in high-risk urban } \\
\text { areas especially slums. }\end{array}$ \\
\hline \multirow[b]{2}{*}{ Peru } & $\begin{array}{l}\text { National } \\
\text { Development } \\
\text { Plan (2011) }\end{array}$ & $\begin{array}{l}\text { Conservation of biodiversity and } \\
\text { ecosystems, integrated watershed } \\
\text { management, organic agriculture and } \\
\text { agroforestry, watershed management that } \\
\text { takes climate change adaptation into } \\
\text { account. }\end{array}$ & $\begin{array}{l}\text { Local populations ought to manage } \\
\text { natural resources, but does not make } \\
\text { link with adaptation explicit. }\end{array}$ & $\begin{array}{l}\text { Ensure that local populations and } \\
\text { production systems are adapted to } \\
\text { climate change. Integrate adaptation } \\
\text { considerations into infrastructure (not } \\
\text { clear if rural or urban). Integrate } \\
\text { climate change adaptation concerns } \\
\text { into regional and local policies. }\end{array}$ & $\begin{array}{l}\text { Ensure that local populations and } \\
\text { production systems are adapted to } \\
\text { climate change. Integrate adaptation } \\
\text { considerations into infrastructure (not } \\
\text { clear if rural or urban). Integrate } \\
\text { climate change adaptation concerns } \\
\text { into regional and local policies. }\end{array}$ \\
\hline & $\begin{array}{l}\text { Climate } \\
\text { Change Plan } \\
\text { (2014) }\end{array}$ & $\begin{array}{l}\text { Notes that ecosystems are essential for } \\
\text { livelihoods and therefore need to be well } \\
\text { managed in the face of climate change. } \\
\text { Lists the conservation of fragile ecosystems } \\
\text { as a priority adaptation measure. Other } \\
\text { adaptation measures include organic } \\
\text { agriculture to conserve soil, reforestation } \\
\text { (particularly around the Rio Corrientes } \\
\text { watershed), watershed rehabilitation, and } \\
\text { ecosystem based adaptation in coastal } \\
\text { areas. }\end{array}$ & $\begin{array}{l}\text { Notes that ecosystems are essential for } \\
\text { livelihoods and therefore need to be } \\
\text { well managed in the face of climate } \\
\text { change. }\end{array}$ & $\begin{array}{l}\text { Highlights the need for technical } \\
\text { assistance to integrate climate } \\
\text { change into territorial management } \\
\text { and planning, and into rural and } \\
\text { urban development. Specific project } \\
\text { on climate-resilient development in } \\
\text { Piura and Tumbes regions. }\end{array}$ & $\begin{array}{l}\text { Highlights need for technica } \\
\text { assistance to integrate climate into } \\
\text { territorial management and planning } \\
\text { and into rural and urban } \\
\text { development. Promotion of climate- } \\
\text { resilient cities explicitly mentioned. }\end{array}$ \\
\hline
\end{tabular}




\begin{tabular}{|c|c|c|c|c|c|}
\hline Country & Plan & Biodiversity and ecosystems & Livelihoods and poverty reduction & Rural development & Urban development \\
\hline \multirow[t]{2}{*}{ Philippines } & $\begin{array}{l}\text { National } \\
\text { Development } \\
\text { Plan (2011) }\end{array}$ & $\begin{array}{l}\text { Ecosystem-based adaptation explicitly } \\
\text { mentioned, e.g. integrated water resource } \\
\text { management and sustainable land } \\
\text { management. Emphasised as a key } \\
\text { approach to climate change adaptation. }\end{array}$ & $\begin{array}{l}\text { Notes that climate change and risks } \\
\text { from natural disasters amplify the } \\
\text { connection between poverty and } \\
\text { environmental degradation and that } \\
\text { better environmental management can } \\
\text { lead to more livelihood opportunities } \\
\text { and increase resiliency of the poor. } \\
\text { Aims to mainstream adaptation into } \\
\text { social development. }\end{array}$ & $\begin{array}{l}\text { Climate change adaptation to be fully } \\
\text { integrated into agriculture and fishing } \\
\text { practices and infrastructure. }\end{array}$ & $\begin{array}{l}\text { Housing construction and land use } \\
\text { planning must be tackled within an } \\
\text { action plan for climate change and } \\
\text { disaster risk management. } \\
\text { Emphasises need to institutionalise } \\
\text { adaptation and disaster risk reduction } \\
\text { in infrastructure development. }\end{array}$ \\
\hline & $\begin{array}{l}\text { Climate } \\
\text { Change Plan } \\
\quad(2011)\end{array}$ & $\begin{array}{l}\text { Highlights ecosystem-based management } \\
\text { to increase resilience. }\end{array}$ & $\begin{array}{l}\text { Forest protection, an adaptation } \\
\text { measure, helps protect livelihoods. }\end{array}$ & $\begin{array}{l}\text { Focused on creating sustainable, } \\
\text { climate-resilient livelihoods, notably } \\
\text { in rural areas. }\end{array}$ & $\begin{array}{l}\text { Notes that a priority is promoting } \\
\text { climate-resilient, sustainable cities } \\
\text { and municipalities. These are called } \\
\text { "ecotowns". }\end{array}$ \\
\hline \multirow[b]{2}{*}{$\begin{array}{l}\text { Solomon } \\
\text { Islands }\end{array}$} & $\begin{array}{l}\text { National } \\
\text { Development } \\
\text { Plan (2011) }\end{array}$ & $\begin{array}{l}\text { Promotes integrated agriculture and land } \\
\text { management strategies, and the } \\
\text { rehabilitation of agro-ecosystems - but does } \\
\text { not explicitly link these to adaptation. }\end{array}$ & $\begin{array}{l}\text { Mentions adapting to climate change } \\
\text { for food production. }\end{array}$ & & $\begin{array}{l}\text { Notes the need for more effective } \\
\text { urban planning processes to be } \\
\text { better prepared for natural disasters. }\end{array}$ \\
\hline & $\begin{array}{l}\text { Climate } \\
\text { Change Plan } \\
(2012)\end{array}$ & $\begin{array}{l}\text { Notes the intention to plan and implement } \\
\text { ecosystem-based vulnerability assessments } \\
\text { and related adaptation programmes }\end{array}$ & $\begin{array}{l}\text { Notes the threat that sea level rise } \\
\text { poses to livelihoods. Aims to increase } \\
\text { the resilience of food production; } \\
\text { integrate climate change adaption } \\
\text { strategies into tourism. }\end{array}$ & $\begin{array}{l}\text { Intends to undertake risk reduction } \\
\text { and vulnerability assessments of } \\
\text { rural communities, and to plan and } \\
\text { implement adaptation actions. }\end{array}$ & $\begin{array}{l}\text { Notes intention to undertake risk } \\
\text { reduction and vulnerability } \\
\text { assessments of urban settlements, } \\
\text { and to plan and implement } \\
\text { adaptation actions. Working to } \\
\text { climate-proof infrastructure. }\end{array}$ \\
\hline \multirow[b]{2}{*}{ Tanzania } & $\begin{array}{l}\text { National } \\
\text { Development } \\
\text { Plan (2011) }\end{array}$ & $\begin{array}{l}\text { Has plans for agroforestry and } \\
\text { protecting/extending coastal ecosystems, } \\
\text { but not explicitly linked to adaptation. } \\
\text { Watershed management is linked to } \\
\text { adaptation. }\end{array}$ & $\begin{array}{l}\text { The poor are the most vulnerable to } \\
\text { climate change, but adaptation } \\
\text { measures do not address livelihoods. }\end{array}$ & & \\
\hline & $\begin{array}{l}\text { Climate } \\
\text { Change Plan } \\
\text { (2012) }\end{array}$ & $\begin{array}{l}\text { Conservation of water catchments, } \\
\text { conservation of coastal and marine } \\
\text { ecosystems, forests and biodiversity, use of } \\
\text { adaptive species, protecting aquatic } \\
\text { ecosystems. }\end{array}$ & $\begin{array}{l}\text { Links climate change adaptation in } \\
\text { water resource management linked to } \\
\text { sustaining livelihoods. Supports } \\
\text { alternative livelihood activities for forest, } \\
\text { fishing and coastal communities to } \\
\text { reduce dependence on climate- } \\
\text { vulnerable activities. Sustainable forest } \\
\text { management, agriculture, fishing, and } \\
\text { tourism also linked to livelihoods. }\end{array}$ & $\begin{array}{l}\text { Detailed adaptation plan for } \\
\text { agriculture sector - does not explicitly } \\
\text { say "rural development" but this } \\
\text { seems implicit. Also has an } \\
\text { adaptation plan for integrating } \\
\text { adaptation into land use - promoting } \\
\text { sustainable land use and land } \\
\text { management systems. }\end{array}$ & $\begin{array}{l}\text { Promoting building codes and } \\
\text { standards to integrate adaptation } \\
\text { considerations into housing and } \\
\text { infrastructure }\end{array}$ \\
\hline \multirow[b]{2}{*}{ Tunisia } & $\begin{array}{l}\text { National } \\
\text { Development } \\
\text { Plan (2010) }\end{array}$ & & & & $\begin{array}{l}\text { Mentions reducing the negative } \\
\text { effects of climate change in cities. }\end{array}$ \\
\hline & $\begin{array}{l}\text { Development } \\
\text { Strategy for } \\
\text { "New Tunisia" } \\
\quad(2012)\end{array}$ & $\begin{array}{l}\text { Protection of marine ecosystems, seemingly } \\
\text { linked to reducing coastal erosion, but not } \\
\text { explicitly linked to adaptation. Focus also on } \\
\text { protecting biodiversity and ecosystems to } \\
\text { reduce desertification, but not explicitly } \\
\text { linked to adaptation. }\end{array}$ & & & \\
\hline
\end{tabular}




\begin{tabular}{|c|c|c|c|c|c|}
\hline Country & Plan & Biodiversity and ecosystems & Livelihoods and poverty reduction & Rural development & Urban development \\
\hline & $\begin{array}{l}\text { National } \\
\text { Sustainable } \\
\text { Development } \\
\text { Strategy } \\
(2014)\end{array}$ & $\begin{array}{l}\text { Combatting coastal erosion by preserving } \\
\text { ecosystems (even though not explicitly } \\
\text { linked to adaptation); reforestation and } \\
\text { agroforestry mentioned as methods to } \\
\text { combat desertification }\end{array}$ & & $\begin{array}{l}\text { Adapting agricultural development to } \\
\text { climate change }\end{array}$ & $\begin{array}{l}\text { Emphasise adapting buildings to the } \\
\text { specificities of the Tunisian climate. }\end{array}$ \\
\hline & $\begin{array}{l}\text { National } \\
\text { Climate } \\
\text { Change } \\
\text { Strategy } \\
(2012)\end{array}$ & $\begin{array}{l}\text { Sustainable forest } \\
\text { conservation agriculture and protection of } \\
\text { watersheds mentioned as adaptation } \\
\text { measures. }\end{array}$ & $\begin{array}{l}\text { Subsistence means to be adapted to } \\
\text { take climate change into account e.g. } \\
\text { growing new kinds of vegetables, using } \\
\text { new storage techniques. }\end{array}$ & $\begin{array}{l}\text { Ensuring that any new developments } \\
\text { (urban or rural) avoid high risk zones }\end{array}$ & $\begin{array}{l}\text { Buildings and infrastructure to take } \\
\text { climate risks into account e.g. in the } \\
\text { choice of their construction materials, } \\
\text { integrating adaptation considerations } \\
\text { into building norms and standards. }\end{array}$ \\
\hline \multirow{2}{*}{ Viet Nam } & $\begin{array}{l}\text { National } \\
\text { Development } \\
\text { Plan (2011) }\end{array}$ & $\begin{array}{l}\text { Afforestation programmes part of } \\
\text { environmental protection and climate } \\
\text { change strategy. }\end{array}$ & & $\begin{array}{l}\text { Responding to climate change } \\
\text { mentioned in section on "developing } \\
\text { regions", covering both rural and } \\
\text { urban areas. }\end{array}$ & $\begin{array}{l}\text { Responding to climate change } \\
\text { mentioned in section on "developing } \\
\text { regions", covering both rural and } \\
\text { urban areas. }\end{array}$ \\
\hline & $\begin{array}{l}\text { Climate } \\
\text { Change Plan } \\
\text { (2011) }\end{array}$ & $\begin{array}{l}\text { Adaptation approaches include planting } \\
\text { green belts, protecting biodiversity and } \\
\text { ecosystems, sustainably managing forests. }\end{array}$ & $\begin{array}{l}\text { Notes need to adjust, develop and } \\
\text { diversify livelihoods and production } \\
\text { practices to adapt to a changing climate } \\
\text { and rising sea levels. Climate change } \\
\text { linked closely to food security. }\end{array}$ & $\begin{array}{l}\text { Sustainable agricultural development } \\
\text { emphasised in the face of climate. }\end{array}$ & $\begin{array}{l}\text { Developing green urban and } \\
\text { residential areas, developing green } \\
\text { belts to protect urban areas }\end{array}$ \\
\hline \multirow[b]{2}{*}{ Zambia } & $\begin{array}{l}\text { National } \\
\text { Development } \\
\text { Plan (2011) }\end{array}$ & $\begin{array}{l}\text { Promotes sustainable land and water } \\
\text { management, including agroforestry, } \\
\text { wetlands, conservation farming as } \\
\text { adaptation strategies. }\end{array}$ & $\begin{array}{l}\text { Agriculture is central to livelihoods, and } \\
\text { adaptation is well integrated into the } \\
\text { section on agriculture, but the link with } \\
\text { adaptation is not explicit. }\end{array}$ & $\begin{array}{l}\text { Will enhance rural land use } \\
\text { management to better reduce climate } \\
\text { change vulnerability. Has the } \\
\text { objective to ensure that adaptation } \\
\text { issues are integrated into local } \\
\text { government and district plans and to } \\
\text { undertake vulnerability assessments } \\
\text { at district level. All water-related } \\
\text { infrastructure to be climate-proofed, } \\
\text { e.g. dams. }\end{array}$ & $\begin{array}{l}\text { Will enhance urban land use } \\
\text { management and urban planning to } \\
\text { better reduce climate change } \\
\text { vulnerability, mainstreaming disaster } \\
\text { risk management into infrastructure } \\
\text { development, design standards and } \\
\text { codes e.g. for water, energy, roads, } \\
\text { bridges, railways. }\end{array}$ \\
\hline & $\begin{array}{l}\text { Climate } \\
\text { Change Plan } \\
\quad(2013)\end{array}$ & $\begin{array}{l}\text { Promoting conservation agriculture and } \\
\text { agroforestry to combat soil and land } \\
\text { degradation as an adaptation technique. } \\
\text { Integration of afforestation with aquaculture } \\
\text { as an adaptation technique in the fisheries } \\
\text { sector. }\end{array}$ & $\begin{array}{l}\text { Agriculture explicitly linked to } \\
\text { livelihoods and to vulnerability to } \\
\text { climate change - encourages } \\
\text { adaptation in methods to grow crops. } \\
\text { Forestry also explicitly linked to } \\
\text { livelihoods, promotes afforestation and } \\
\text { reforestation, and agroforestry as a way } \\
\text { to meet both food and fuelwood needs. } \\
\text { Also promotes alternative livelihood } \\
\text { sources (e.g. bee keeping) to protect } \\
\text { forest resources, which are needed as } \\
\text { an adaptation measure. }\end{array}$ & $\begin{array}{l}\text { Diversification of rural economies as } \\
\text { an adaptation measure, to reduce } \\
\text { dependence on climate-sensitive } \\
\text { sectors. Highlights need for rural } \\
\text { climate change action plan. }\end{array}$ & $\begin{array}{l}\text { Highlights need for urban climate } \\
\text { change action plan, and for green } \\
\text { spaces in urban centres to moderate } \\
\text { temperatures. Revising building } \\
\text { codes to factor in climate change. }\end{array}$ \\
\hline
\end{tabular}

Source: see bibliography for the list of National Development Plans and Climate Change Plans reviewed.

Note: The legend is as follows. (a) White = link with adaptation not present; (b) Light blue = link with adaptation is implicit in the text; (c) Dark blue = link with adaptation is explicitly mentioned. 


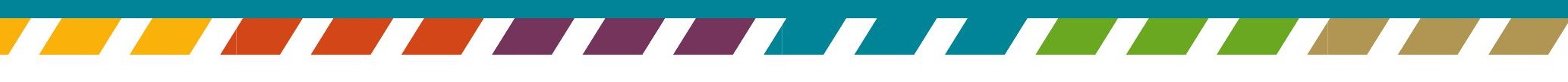

